\title{
التسعير والأثمان
}

\section{في فقه شيخ الإسلام ابن تيمية}

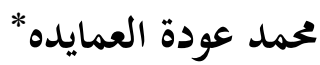

\section{مقدمة}

يسعى الإنسان لإشباع حاجاته من خلال الشراء والمتمثل بالطلب الذي يتحدد بمقدار المنفعة التي يمكن الحصول عليها من السلعة، وبتلاقي هذا الطلب مع عرض المنتجين لسلعهم يتحدد السعر، وقد اختلف فقهاء الإسلام حول التسعير، بين بجيز ومحرم وبجيز بشروط، وقد تناول شيخ الإسلام ابن تيمية هذا الموضوع بشيء من التفصيل حيث بين خلافات الفقهاء وأدلة كل فريق، وقسم التسعير إلى تسعير أموال، ويقصد به تسعير السلع، وتسعير أعمال ويقصد به تحديد الأجرة، إضافة إلى أنه تحدث عن البيع بأقل أو أكثر من التسعيرة وحكم كل نوع، ليخلص في النهاية إلى رأيه بالتسعير القائل:الأصل أن تتحدد الأسعار من خلال العرض والطلب ولكن إذا حصل تدخل مفتعل أعاق عمل هذه الآلية وأصبحت عاجزة عن أداء عملها، عندها لولي الأمر التدخل وتحديد السعر العادل من خلال التفاوض مع وجهاء السوق وبرضاهم وأصبح يعتمد على هذا الرأي الكثير من الكتاب ويستأنسون به وتم الحديث عن ذلك من خلال خمسة مباحث: - المبحث الأول: نظرية القيمة. - المبحث الثاني: قوى السوق والعرض والطلب.

$$
\text { - المبحث الثالث: التسعير. }
$$

دكتوراه في الإقتصاد الإسلامي من جامعة القرآن الكريع والعلوم الإسلامية في السودان عام 2000 ، يعمل حاليًا في قسم البرامج الدينية في 


\section{نظرية القيمة}

ميز شيخ الإسلام ابن تيمية وفرق بين القيمة والثمن،موضحاً أن الثمن ما اتفق عليه البائع والمشتري برضاهما بعيداً عن الاحتكار والغش والتدليس، أما القيمة فهي ما تعارف عليه أهل السوق فيما بينهم، 1 فيقول (أما إذا كان الحق قد فات مثل الوطء في النكاح الفاسد والعمل في المؤاجرات والمضاربات والغبن في المبيع، فالقيمة ليست مثلاً له وإنما بحب في بعض المواضع كالمتلف والمغصوب الذي تعذر مثله للضرورة، إذ ليس هناك شيء يوجب أقرب إلى الحق من القيمة، فكان ذلك هو العدل الممكن كما قلنا مثل ذلك في القصاص ودية الخطأ وأرش الجراح،واعتبرنا القيمة

$$
\text { بتقويم الناس، إذ ليس هناك متعاقدان تراضياً بشيء). }
$$

وتختلف القيمة عن الثمن بأن القيمة ترتبط بالتوازن في السوق بعكس الثمن الذي قد يرتفع أو ينخفض، وكذلك تتصف القيمة بالثبات، بعكس السعر الذي لا يتصف بالثبات وقد يتذبذب بين ارتفاع ونزول.

وثار الجدل بين علماء الاقتصاد حول فكرة القيمة وكيفية تحديدها وأسباها، بين قائل إفا تحدد على أساس منفعة السلعة، وقائل آخر إها تحدد على أساس المجهود المبذول في إنتاج السلعة وآخر يقول على أساس ندرتا، وقائل على أساس نفقة إنتاجها وفي ما يلي عرض لهذه النظريات:

1- نظرية نفقة الإنتاج وأول من قال بها (آدم سميث)تلاه (ريكاردو) وأخيراً (كارل ماركس)، وحسب هذه النظرية تتحدد القيمة للسلعة حسب كمية العمل اللازم لإنتاجها، على افتراض أن الذي قام بعملها عامل يعمل في ظروف إنتاج عادية، سواء كان هذا العمل مباشراً أو غير مباشر، متمثلاً في استخدام الآلات، إلا أنه يؤخذ على هذه النظرية عدة مآخذ منها، أن نفقة الإنتاج ليست سبباً للقيمة، بل نتيجة أشياء ذات قيمة، وأكبر دليل على ذلك أنه قد ينفق في إنتاج سلعة الكثير، ولكن ليس لهذه السلعة قيمة، إذا لم تؤد منفعة لمستهلكها، ${ }^{3}$ وكذلك لم تعط تفسيراً لبعض السلع التي تكون نفقات إنتاجها قليلة وأسعارها عالية كالموهرات والأحجار الكريمة، كما لا تعطي تفسيراً لارتفاع السعر نتيجة قلة العرض أو مرور الوقت على السلعة كالتحف، ثم طوّر ستيورت مل هذه النظرية، بأن جعل

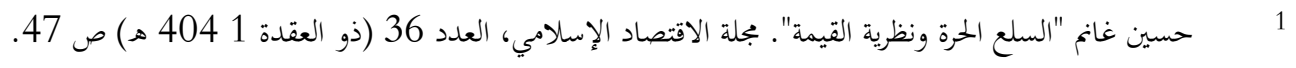

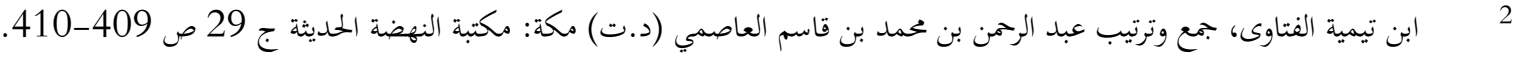

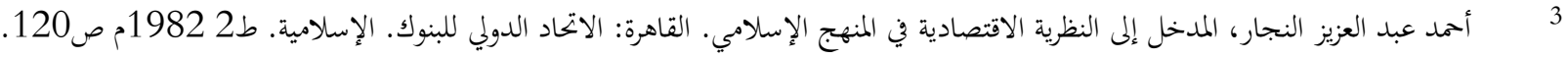
4 
قيمة السلعة لا تتحدد بالعمل فحسب، بل بتضافر جميع نفقات عوامل الإنتاج، بعيداً عن الاحتكار والفترة الطويلة. وحتى هذه النظرية بثوها الجديد لم تسلم، إذ إنا لم تأخذ بالحسبان اختلاف قدرات المنتجين في خفض تكلفة الإنتاج، مما يجعل أثمان السلع تختلف باختلاف هذه القدرات، والأهم أن هذه النظرية بجميع وجوهها اقتصرت على جانب العرض،مهملة جانب الطلب على السلع من قبل المستهلكين.

2- نظرية المنفعة الحدية، ودعاة هذه المدرسة (جيفونز) و(منجر) و(فالراس)، وتقوم على أن منفعة آخر وححة يقف عندها الإشباع من السلعة هي التي تحدد القيمة والمنفعة الحمدية، ويؤخذ على هذه النظرية أهما لا تفسر قلة أثمان بعض السلع ذات المنفعة الكبيرة وارتفاع أثمان بعض السلع ذات المنفعة المتدنية كالأحجار الكريمة، 5 وعلى عكس النظرية الأولى اهتمت هذه النظرية بجانب الطلب مهملة جانب العرض.

3-نظرية مارشال، وصاحبها (ألفرد مارشال)، وقد جمع بين نظرية المنفعة ونظرية نفقة الإنتاج، وقال إن سعر

أي سلعة يتحدد نتيجة تفاعل قوتين أساسيتين هما:

منفعة السلعة ويحددها طلب المستهلك "الطلب"، ونفقة الإنتاج ويحددها عرض المنتج"العرض"،فعند ارتفاع السعر يقل طلب المستهلك، ويزداد عرض المنتج، ويستمر التفاعل حتى يتم الوصول إلى نفقة التوازن، وهي السعر الذي يتساوى فيه الطلب والعرض تماماً.6

وإذا عدنا إلى فقه شيخ الإسلام وجدنا أنه سبق(ألفرد مارشال) في بيان القيمة، وأغا تتحدد حسب العرض والطلب،ولنذكر مما ذكر نصين فقط يبينان سبقه، يقول (فإذا كان الناس يبيعون سلعهم على الوجه المعروف من غير

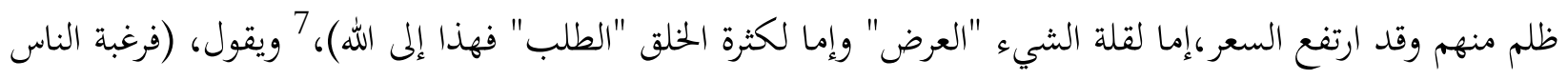
كثيرة الاختلاف والتنوع، فإِها تختلف بكثرة المطلوب وقلته، فعند قلته يرغب فيه من لا يرغب فيه عند الكثرة، وبكثرة الطلاب وقلتهم، فأن ما كثر طالبوه يرتفع ثمنه بخلاف ما قل طالبوه، وبحسب قلة الحاجة وكثرتا وقوتما وضعفها، فعند

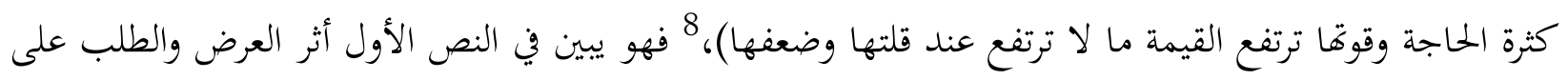

$$
\text { } 5
$$

6 6 6

$$
\begin{array}{r}
7 \\
7
\end{array}
$$


ارتفاع الأسعار والخفاضها، إذ ترتفع بسبب قلة العرض أو زيادة الطلب حسب قوله، أما في النص الآخر فهو يبين بوضوح جلي بأن كثرة الطلب ترفع السلع وقلته تخفضه، ويضيف عاملاً آخر هو أهمية الحاجة ودرجة المنفعة التي تشبعها، فعندما تكون السلعة ذات أهمية وتشبع منفعة كبيرة ترتفع قيمتها، بعكس ما إذا كانت المنفعة التي تشبعها

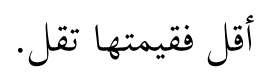

وكما أسلفنا فشأن السوق في الاقتصاد الإسلامي تتساوى فيه القيمة والسعر في الأحوال العادية.

$$
\text { ولتطابق السعر مع القيمة فوائد اقتصادية في السوق الإسلامية،ومن أهمها: }
$$

1- التخصيص الصحيح للموارد،حيث إن المنظم المسلم يستطيع أن يعرض جميع الكمية من السلعة عند السعر الذي يساوي قيمتها، والذي بدوره يعادل إجمالي التكلفة المتوسطة، ولكون السعر والتكلفة دالة في الكمية، أي أن المنظم المسلم يكون في حالة توازن عند إنتاج السلعة إذا تساوى السعر مع التكلفة المتوسطة، وهذا يؤدي إلى بسط الموارد المتاحة بشكل يمكن المستهلك من تحقيق أقصى إشباع مكن له.

2- التوزيع العادل للدخل القومي، الدخل القومي الذي هو من صنع مختلف عناصر الإنتاج، يجب أن يوزع عليها، ويي الاقتصاد الإسلامي تتتلف عناصر الإنتاج عن الاقتصاد الوضعي من حيث تحديدها واستحقاقها، فالأجر مثلاً يتحدد في السوق ويستحق بمجرد مساهمة العامل في العملية الإنتاجية، أما الربح فيتم تحديده كنتيجة للنشاط الاقتصادي ولا يستحق إلا بعد بيع الناتج، وفي السوق الإسلامي المنضبط بالضوابط الإسلامية يتحدد الأجر العادل، وكذلك فإن الربح لعناصر الإنتاج لن يكون على حساب المشتري، بل عند السعر العادل المتفق مع القيمة فإن أي ربح إضافي سيكون صفراً، وبذلك تقوم علاقات التبادل في الإسلام على التكافؤ، ولا تحدث تغبراً في نمط توزيع الدخل القومي لصالح فئة من المجتمع على حساب فئة أخرى، ولاسيما أصحاب العناصر الربحية، وبذا فإن السعر العادل للسلع الاستهلاكية يمثل أحد شروط التوزيع العادل للدخل القومي. 9

ويرى الباحث أن القيمة هي السعر الذي يتعارف عليه الناس، والذي يتولد نتيجة التقاء الطلب الحقيقي المنضبط للسلع مع العرض الحقيقي البعيد عن شوائب السوق من احتكار وغيره،وفي الأحوال العادية تعتبر القيمة هي عبد الله عبد العزيز عابد ،"تطابق السعر الإسلامي مع القيمة وأثره على الأداء الاقتصادي."بجة الاقتصاد الإسلامي، العدد59 (شوال 1406 ه( 
السعر، أما في الأحوال غير العادية التي يرتفع فيها السعر ينخفض، فإن الذي يتحدد هو السعر وليس القيمة ومع الزمن يعود هذا السعر إلى الانخفاض أو الارتفاع حتى يتفق مع القيمة.

وتبرز أهمية آراء ابن تيمية في اختياره للقيمة أو ثثن المثل كمعيار للتعويض أو عند الإجبار على البيع، لأن ثمن المثل أو القيمة يمثل تكلفة السلعة إضافة إلى هامش ربحي معقول، يقبل به كل إنسان عنده دين وضمير ولا يحب ظلم الناس وأكل أموالهم بالباطل،وكذلك في سبقه لعلماء الاقتصاد الغربيين وتحديده للقيمة عن طريق العرض والطلب، الذي تخبط فيه علماء الاقتصاد الوضعي بين مركز على العرض ومهمل للطلب، أو مركز على الطلب ومهمل للعرض.

\section{قوى السوق}

تقوم قوى السوق على أمرين هما العرض والطلب، فالعرض يقصد به "الكميات المختلفة من السلعة، التي يكون المنتج على استعداد لطرحها في السوق، عند الأثمان المختلفة خلال فترة معينة"، 10 ويتأثر بعدة أمور منها، هدف المشروع وهو تحقيق أقصى ربح وثمن السلعة المنتجة وأثمان السلع الأخرى المنتجة في فروع الإنتاج الأخرى وأثمان عناصر الإنتاج والتقدم التكنولوجي.11 أما الطلب فيقصد به "الكميات المختلفة من السلعة التي يكون المستهلك الفرد على استعداد لشرائها عند الأثمان المختلفة خلال فترة معينة"، 12 ويتأثر بثمن السلعة ودخل المستهلك الفرد على السلع الأخرى سواء المكملة أو البديلة أو الأخرى، وأذواق المستهلكين وعاداقم وأخلاقهم. 13 وكي يترك تحديد السعر للعرض والطلب يجب أن يتصف السوق بالمنافسة الكاملة، وحتى يتحقق ذلك لا بد من توافر شروط منها:

1- أن يكون عدد البائعين والمشترين صغيراً بحيث لا يؤثر تأثيراً واضحاً على ثمن السلعة.

2- أن يتاح للبائعين والمشترين المعرفة الكاملة بأحوال السوق.

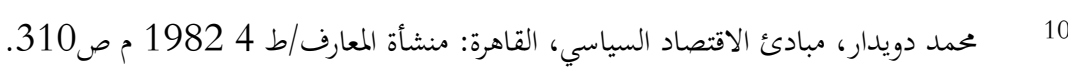

$$
\begin{aligned}
& 11 \\
& 12 \\
& 13
\end{aligned}
$$




$$
\text { 3- 3 - 3حانس وتقارب وحدات السلع. }
$$

$$
\text { 4- خلو السوق من التدخل سواء من قبل الدولة أو اتفاق البائعين أو المشترين.14 }
$$

ويتحدد السعر بتفاعل ظروف العرض مع ظروف الطلب وصولاً إلى سعر توازن وسعر تعادل تتساوى عنده الكمية المطلوبة مع الكمية المعروضة خلال فترة زمنية، 15 ويكن التعبير عن ذلك بيانياً كما يلي:

نفترض أن الخط الأفقي أس يمثل الكمية والخط العمودي أص يمثل السعر والمنحنى ط ط يمثل منحنى الطلب، والمنحنى ع ع يمثل منحنى العرض، فيلتقيان في النقطة ن حيث أب سعر التوازن، أج كمية التوازن التي تتساوى فيها الكمية المطلوبة مع الكمية المعروضة ويستمر ثبات هذا السعر ما دامت ظروف العرض وظروف الطلب كما هي عليه.

والآن نفترض أن أصحاب السلع طلبوا سعر أد، فعند هذا السعر تنقص الكمية المطلوبة إلى ده، في حين تزيد الكمية المعروضة إلى دو، وهذا يعني أن الكمية المعروضة تزيد على الكمية المطلوبة بمقدار وهه، فيؤدي إلى الخفاض الأسعار وبالتالي إلى سعر التوازن حتى يتمكن التجار من تصريف ما لديهم من إنتاج ولو فرضنا على العكس أن المشترين فرضوا السعر أز أقل من سعر التوازن،

$$
\begin{aligned}
& 14 \\
& \text { كممد عبد المنعم عفر، الاقتصاد الإسلامي ج } 3 \text { الاقتصاد الجزئي، جدة: دار البيان العربي للطباعة والنشر. والتوزيع، ط. } 11985 \text { مج } 3
\end{aligned}
$$




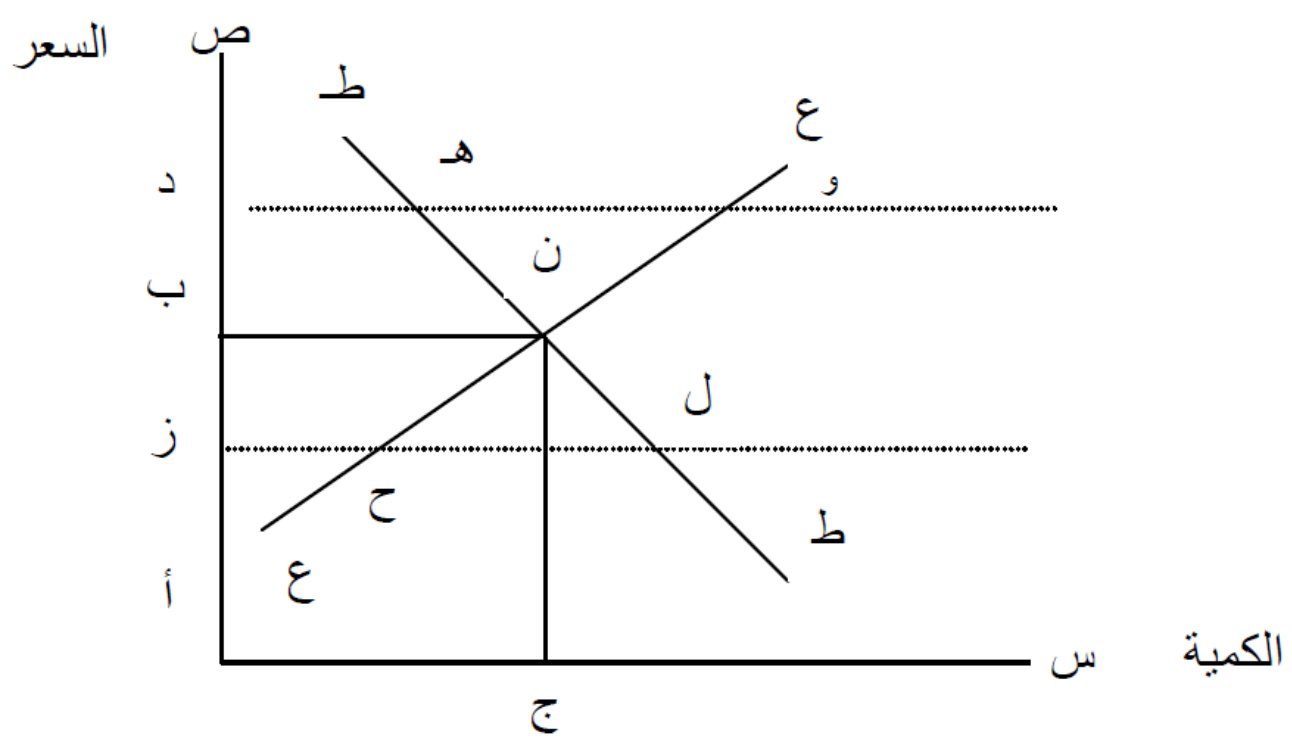

فإن الكمية المطلوبة ستصبح زل، والكمية المعروضة زح، بمعنى أن ح ل، مقدار النقص المطلوب، فيؤدي ذلك إلى تنافس المشترين على السلعة لإشباع حاجاتم فيرتفع السعر إلى التوازن أب. 16

ففي الحالة الأولى يرى شيخ الإسلام ابن تيمية أن لا تتدخل الدولة في السعر، أما إذا حدثت ظروف أخرى خارجة، عطلت عمل العرض والطلب عن تحديد السعر، أو حدث تلاعب بقصد التأثير على قوى السوق وتعطيلها أو نتيجة ظروف خارجة عن إرادة المستهلك كالحروب فعندها يجوز تدخل الدولة لإعادة الفاعلية إلى قوى السوق. 17 وحتى منتصف القرن الثامن عشر لم تتبلور فكرة واضحة في الاقتصاد الوضعي عن آلية السوق "العرض والطلب" وتحديد الأسعار، حتى جاء الاقتصادي الإنجليزي (ألفرد مارشال) الذي بين أن سعر السلعة يتحدد نتيجة تفاعل منفعة السلعة "طلب المستهلك" ونفقة إنتاجها "عرض المنتجين" وعند ارتفاع سعر السلعة يقل طلب المستهلكين لها ويزيد عرض المنتجين إلى أن يصل السوق إلى نقطة التوازن أي السعر الذي يتساوى فيه العرض والطلب، 18 ولكن هذه الفكرة التي جاء بها (ألفرد مارشال) في القرن الثامن عشر سبقه إليها ابن تيمية في القرن الثالث عشر للميلاد، إذ أشار إلى قانون العرض والطلب في قوله، (فإذا كان الناس يبعون سلعهم على الوجه المعروف

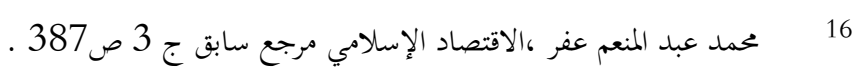

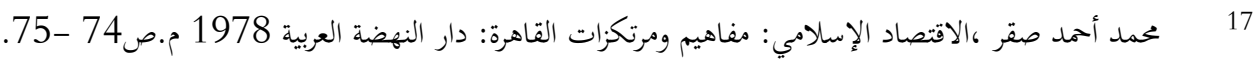

$$
\begin{aligned}
& 18
\end{aligned}
$$


من غير ظلم منهم وقد ارتفع السعر إما لقلة الشيء وإما لكثرة الخلق، فهذا إلى الله، فإلزام الخلق أن يبيعوا بقيمة بعينها إكراه بغير حق)، 19 فهو يتحدث هنا عن حالة ارتفاع الأسعار ننيجة قلة العرض، والتي عبر عنها بقلة الشيء أو كثرة الطلب التي عبر عنها بكثرة الخلق، فالارتفاع هنا أمر طبيعي يعود إلى وضعه الطبيعي بتفعيل قانون العرض والطلب ويشير كذلك إلى ارتفاع السعر نتيجة زيادة الطلب مع ثبات العرض فيقول (ومعلوم أن الشيء إذا رغب الناس في المزايدة فيه فإذا كان صاحبه قد بذله كما جرت به العادة ولكن الناس تزايدوا فيه فهنا لا يسعّر عليهم). وقد كان لشيخ الإسلام فكرة واضحة عن قوى السوق التي تحدد السعر فيقول، (فالغلاء بارتفاع الأسعار والرخص بانخفاضها هما من جملة الحوادث التي لا خالق لها إلا الله وحده ولا يكون شيء منها إلا بمشيئته وقدرته، لكن هو سبحانه قد جعل بعض أفعال العباد سبباً في بعض الحوادث، كما جعل قتل القاتل سبباً في موت المقتول، وجعل ارتفاع الأسعار قد يكون بسبب ظلم العباد،وانخفاضها قد يكون بسبب إحسان بعض الناس)، 21 ويقول (إن الغلاء والرخص لا تنحصر أسبابه في ظلم بعض، بل قد يكون سببه قلة ما يخلق أو يجلب من ذلك المال المطلوب فإذا كثرت الرغبات في الشيء وقل المرغوب فيه ارتفع سعره، فإذا كثر وقلت الرغبات فيه الخفض سعره، والقلة والكثرة قد لا تكون بسبب من العباد وقد تكون بسبب لا ظلم فيه، وقد تكون بسبب فيه ظلمهوالله تعالى يجعل الرغبات في القلوب).

فنجده رحمه الله يرسم قانون العرض والطلب أحسن رسم حيث بين أن زيادة الطلب على السلعة مع قلة عرضها يرفع سعرها، وهو الذي عبر عنه بقوله، (فإذا كثرت الرغبات في الشيء وقل المرغوب فيه ارتفع سعره)، وإذا زاد العرض وقل الطلب انخفض السعر والذي عبر عنه بقوله: (فإذا كثرت -أي العرض-وقلت الرغبات فيه-أي الطلب - مانفض سعره).

وهنا يبرز حرص شيخ الإسلام ابن تيمية على بيان دور الرغبة في تحديد مستوى السعر، ويبين أن الرغبة عامل مهم وحاسم في تغيير مستوى السعر، فكثرتا ترفع السعر على حين قلتها تخفضه، ومن دقته رحمه الله أنه ربط بين كثرة

$$
\begin{aligned}
& 19 \\
& 20 \text { 20 المرجع السابق ص23. } \\
& 21 \text { ابن تيمية ،الفتاوى ،مرجع سابق ج } 8 \text { ص23 ص520. } \\
& 22
\end{aligned}
$$


الرغبات "الطلب" مع قلة الشيء "العرض" لأن كثرة الرغبات "زيادة الطلب" مع كثرة الشيء "زيادة العرض" أو قلة الرغبات "نقص الطلب" مع قلة الشيء"نقص العرض "قد لا تؤثر في مستوى الأسعار، بل على العكس ففي الحالة الأولى ربما ينزل السعر أكثر رغم زيادة الطلب إذا كان معدل زيادة الإنتاج أكبر من معدل تزايد الرغبات "زيادة الطلب" وقد يؤدي أيضاً إلى ارتفاع السعر في الحالة الثانية رغم قلة الطلب إذا كان معدل انخفاض الإنتاج أكبر من معدل انخفاض الرغبات "الطلب".

وقد ذكر ابن تيمية هنا أن أسباب ارتفاع الأسعار وانخفاضها ليس دائماً مرده إلى قوى السوق بل ذكر مصادر أخرى تؤثر في العرض، مثل الإنتاج المحلي الذي عبر عنه "قلة ما يخلق" واستيراد البضائع الذي عبر عنه "أو يجلب" واستخدام ألفاظاً دقيقة؛ فهو يستخدم لفظ "الظلم" إشارة إلى ارتفاع الأسعار الناتج عن تحكم الباعة الذي يؤدي إلى عدم قيام السوق بعملها بفاعلية ويستخدم لفظ "الرغبات" وهي التي تعكس الحاجات أو الأذواق التي تحدد

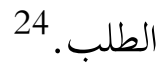

وابن تيمية في حديثه هذا وعندما يربط بين زيادة الطلب وقلة العرض إنما يتحدث عما يسمى اليوم بوظائف متغيرات العرض والطلب، 25 فهو يجمع بين المتغيرين؛ زيادة الطلب وقلة العرض في آن واحد ولكن نجده يتحدث في مواقع أخرى عن هذه المتغيرات منفردة كما مر معنا في قوله (وقد ارتفع السعر إما لقلة الشيء وإما لكثرة الخلق) فذكر قلة العرض المتمثلة بقلة البضاعة وزيادة الطلب المتمثلة بزيادة السكان، وقال (ومعلوم أن الشيء إذا رغب الناس في المزايدة فيه فإذا كان صاحبه قد بذله كما جرت به العادة ولكن الناس تزايدوا فيه فهنا لا يسعّر عليهم) فهنا تحدث عن ثبات العرض وزيادة الطلب وابن تيمية في حديثه عن ارتفاع الأسعار بأها من الله إنما يدخل عوامل غيبية غير معروفة في آلية السوق.

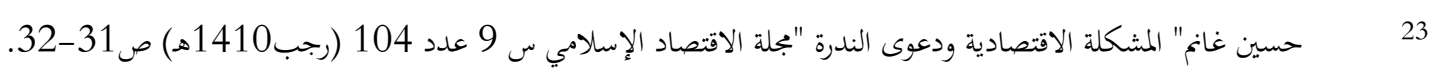

24 Islahi. Adbulazim Ibn taimiyah,s Concept of Market Mechanism. Journal of Research in Islamic Economics (Jeddah) vol 2no 2 (winter 1985)p.56.

25 Ibid.p.56.

26 2 خالد خليل الظاهر ورفيقه، نظام الحسبة: دراسة في الإدارة الاقتصادية للمجتمع العربي المسلم ،عمان:دار المسيرة 1997 م.ص 55. 
تم يتحدث رممه الله في مكان آخر فيقول (إذا عرف ذلك فرغبة الناس كثيرة الاختلاف والتنوع فإنها تختلف بكثرة المطلوب وقلته، فعند قلته يرغب فيه ما لا يرغب فيه عند الكثرة، وبكثرة الطلاب وقلتهم فإذا ما كثر طالبوه يرتفع ثمنه بخلاف ما قل طالبوه،وبحسب قلة الحاجة وكثرتا وقوتما وضغطها، فعند كثرة الحاجة وقوتا ترتفع القيمة ما لا ترتفع عند قلتها وضعفها، وبحسب المعاوض فإن كان ملياً ديناً يرغب في معاوضته بالثمن القليل الذي لا يبذل بمثله لمن يظن عجزه أو مطله أو جحده وبحسب العوض، فقد يرخص فيه إذا كان بنقد رائج ما لا يرخص فيه إذا كان بنقد آخر دونه في الرواج، كالدراهم والدنانير بدمشق في هذه الأوقات فإن المعاوضة بالدراهم هو المعتاد وذلك أن المطلوب من العقود هو التقابض من الطرفين فإذا كان الباذل قادراً على التسليم موفياً بالعهد كان حصول المقصود بالعقد معه، بخلاف ما إذا لم يكن تام القدرة أو تام الوفاء، ومراتب القدرة والوفاء تختلف وهو الخير المذكور في قوله: "فكاتبوهم إن علمتم فيهم خيراً"، 27 قالوا: قوة على الكسب ووفاء على العهد، وهذا يكون في البائع وفي المشتري وفي المؤجر والمستأجر والناكح والمنكوحة، فإن المبيع قد يكون حاضراً وقد يكون غائباً، فسعر الحاضر أقل من سعر الغائب، وكذلك المشتري قد يكون قادراً في الحال على الأداء لأن معه مالاً، وقد لا يكون معه، لكنه يريد أن يقترض أو يبيع السلعة، فالثمن مع الأول أخف).

ومعنى ذلك في اللغة الاقتصادية أن رغبة الناس التي تحدد الطلب تتنوع وتختلف حسب عرض السلع، والذي عبر عنه بكثرة المطلوب وقلته، ويشير إلى التفاعل الطلب مع العرض لتحقيق التوازن من خلال الأسعار، وإن الطلب يختلف باختلاف السعر والذي عبر عنه بقوله، (فعند قلته يرغب فيه ما لا يرغب فيه عند الكثرة)، ويختلف بذلك بالطلب على السلعة والذي عبر عنه بكثرة الطلاب وقلتهم، وعند زيادة الطلب يرتفع السعر بخلاف قلة الطلب وعبر عنه بقوله، (فإن ما كثر طالبوه يرتفع ثمنه بخلاف ما قل طالبه)، وبحسب مدى الرغبة في السلعة والحاجة إليها لتحقيق المنفعة حسب كون السلعة أو الخدمة ضرورية أو شبه ضرورية أو كمالية وهو ما يؤثر على مرونة الطلب على السلعة والخدمة وقد عبر عنه بقوله، (وبحسب قلة الحاجة وكثرتا وقوتا وضعفها )، وعند عدم مرونة الطلب أو انخفاض هذه المرونة وثبات العرض مع زيادة منفعة الحاجة ترتفع قيمتها وعبر عنه بقوله، (فعند كثرة الحاجة وقوما ترتفع القيمة)، بعكس ما إذا زادة مرونة الطلب مع ثبات العرض وعبر عنه بقوله،( ما لا ترتفع عند قلتها وضعفها)، وبحسب

$$
\begin{aligned}
& 27 \text { سورة النور من الآية } 33 . \\
& 28 \text { ابن تيمية، الفتاوى، مرجع سابق. ج } 29 \text { ص 523-525. }
\end{aligned}
$$


المشتري من حيث دخله وغناه ودينه وأخلاقه ووضعه الاجتماعي وعبر عنه بقوله (وبحسب المعاوض فإن كان ملياً ديناً يرغب في معاوضته يالثمن القليل الذي لا يبذل بمثله لمن يظن عجزه أو مطله أو جحده)، ويقصد بمن يظن عجزه صاحب الدخل المتدني، ومطله أو جحده أنه غير قادر على السداد أو راغب فيه،وبحسب العملة أو النقد المدفوع هل هو ذو قوة شرائية كبيرة أو ذو قوة شرائية منخفضة،وعبر عنه بقوله، (وبحسب العوض فقد يرخص فيه إذا كان بنقد رائج ما لا يرخص فيه إذا كان بنقد آخر دونه في الرواج). وبالنظر إلى النص السابق لابن تيمية نجد أنه يقرر ما يلي:

1- أن الرغبة تختلف بحسب توافر أو قلة البضاعة المطلوبة، فالبضاعة تطلب أكثر عند قلتها مما تطلب عند وفرتا وكثرةقا.

2- تتعدد الرغبات أيضاً وتختلف على حسب عدد الراغبين والطالبين، فإذا كان الطلب كثيراً يرتفع السعر بعكس ما إذا كان عددهم قليلاً.

3- وحسب قوة أو ضعف الحاجة لتلك البضاعة، فإذا كان الطلب كبيراً فإن السعر سيرتفع وإذا كان قليلاً فسيقل. 4-ويتفاوت السعر أيضاً حسب الزبون المتعامل معه، فإذا كان غنياً وذا ثقة فإنه سيحصل على سعر أقل من غيره. 5-ويتأثر السعر بنوعية النقد المدفوع، فإذا كان متداولاً بشكل جيد فإن السعر سيكون أقل ممن يدفع بعملة نقد غير متداول بكثرة. 6- يتحدد السعر حسب القدرة على الوفاء بالالتزام فمن لديه القدرة على الوفاء بالالتزام يكصل على سعر أقل من غيره. 


\section{7- وما ينطبق على البيع والأسعار ينطبق على الإجارة والأجرة30}

ويلاحظ أن ابن تيمية يأخذ بالعامل النفسي، إذ إن قلة العرض بتعل الطالبين يعتقدون أن تلك البضاعة

$$
\text { ستتناقص في المستقبل، لذا يزداد طلبهم عليها. }
$$

ويربط بين شدة الحاجة بالإضافة إلى حجم البضاعة كجزء من تكاليف الاستهلاك للفرد مع الأسعار المرتفعة،

$$
\text { وبالمقابل فإن قلة الشعور بحاجة الشيء إضافة إلى قلة عرضه سيعمل على تدني السعر. } 32
$$

ويرى أن عدم التأكد من الوضع المالي للمشتري،ونوعية النقد المدفوع وقدرة المشتري على الوفاء، كل ذلك يؤثر

على الأسعار، وهذا له أهمية ويعتبر مشاركة في التحليل الاقتصادي، إضافة لوعيه لأثر متغيرات العرض والطلب على

ومما يسجل لشيخ الإسلام ابن تيمية في موضوع قوى السوق أنه كشف عن وجود عوامل أخرى تؤثر في السعر، إضافة إلى العرض والطلب،مثل الرغبة في الحصول على الأرباح الفاحشة،ما يدفع إلى الاحتكار وإلى تواطؤ البائعين وحصر البيع في واحد أو جماعة،فعند هذه الحالات يتعطل عمل قانون العرض والطلب. 34

وحسب رأي الاقتصاديين، فإن عوامل الانراف السوق وخروجه عن وضعه الطبيعي تكمن فيما يلي:

$$
\text { 1- عدم معرفة الباعة والمشترين بشكل متساو للأسعار السائدة في السوق. }
$$

2- عدم الاقتصار في التعامل على السعر فقط.وإنما تدخل أمور اجتماعية أخرى مثل العلاقات الاجتماعية

$$
\text { 3ع بعض التجار. . وجود الاحتكارات في البيع والشراء. }
$$

$30 \quad$ Islehi. Abdulazim. Ibn Taimiyah's Concept of Market Mechanism. Journal of Research in Islamic, Economics (Jeddeh) vol. 2no 2Winter 1985 P.57-58.

31 Ibid.p.59.

32 Ibid.p.59.

$33 \quad$ Ibid.p.59.

حمد بن عبد الرمن المنيدل، مناهج الباحثين في الاقتصاد الإسلامي، الرياض :شركة العبيكان للطباعة والنشر، 1406ه، ج2 ص275-276. 


\section{4- تدخل الدولة للحد من الحرية بفرض أسعار جبرية،أو منح امتيازات خاصة لبعض الباعة. 35}

أما في الاقتصاد الإسلامي -وحسب فقه ابن تيمية- فلا يوجد أي جو يعمل على تشجيع عوامل انخراف

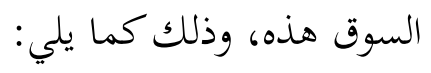

1- بالنسبة إلى العامل الأول منع الإسلام تلقي الجلب وبيع الحاضر للبادي وغبن المسترسل وأعطاهم الخيار إذا علموا بالأسعار، يقول ابن تيمية، (ومن المنكرات تلقي السلع قبل أن تجيء إلى السوق، فإن النبي صلى الله عليه وسلم فى عن ذلك، 36 لما فيه من تغرير البائع،فإنه لا يعرف السعر فيشتري منه المشتري بدون القيمة، ولذلك أثبت

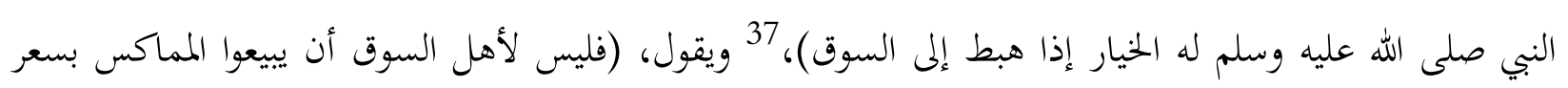
ويبيعوا المسترسل الذي لا يماكس أو من هو جاهل بالسعر بأكثر من ذلك، هذا مما ينكر على الباعة وهو بمنزلة تلقي السلع، فإن القادم جاهل بالسعر وهذا في عنه لما فيه من ضرر المشترين، فإن المقيم إذا توكل للقادم في بيع سلعة يجتاج الناس إليها والقادم لا يعرف السعر ضر ذلك المشتري).

2- أما محاباة التجار أو العلاقات الاجتماعية فليس لها ذكر في السوق الإسلامي، يقول ابن تيمية: (لم يكن

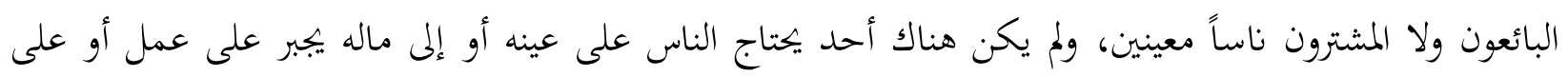
بيع، بل المسلمون كلهم من جنس واحد كلهم يجاهد في سبيل الله).

3- وأما تدخل الدولة في التسعير فقد بين رحمه الله أن الأصل أن يترك السعر يتحقق في السوق عن طريق العرض والطلب، أما إذا تعطل ذلك القانون بفعل مفتعل فعندها لا بد من التسعير لإعادة الحياة إلى قوى السوق، يقول ابن تيمية، (وإذا كانت حاجة الناس تندفع إذا عملوا ما يكفي الناس بحيث يشترى إذ ذاك بالثمن المعروف لن

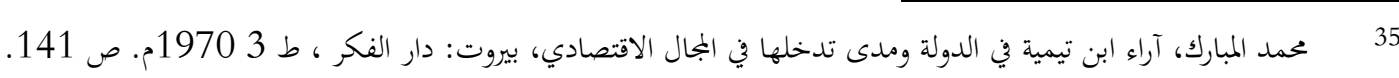

$$
\begin{aligned}
& 36 \text { } 36
\end{aligned}
$$

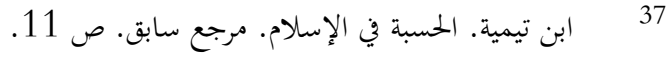

$$
\begin{aligned}
& 38 \\
& 39
\end{aligned}
$$


يحتج إلى تسعير،وأما إذا كانت حاجة الناس لا تندفع إلا بالتسعير العادل، سعر عليهم تسعير عدل لا وكس 40 ولا شطb 42.41

$$
\text { والذي يراه الباحث، }
$$

1- أن شيخ الإسلام سبق علماء الاقتصاد الغربيين، من مثل ألفرد مارشال في الكشف عن قانون العرض

والطلب وتحديده للسعر.

2- كان له -رممه الله- فكرة واضحة عن قوى السوق التي تعمل على تحديد السعر، وبرزت من خلال كتاباته

والنصوص التي نقلناها.

3- أظهر مصطلح الرغبة في تحديد مستوى الأسعار، كون الرغبات تعكس الحاجة والأذواق التي تحدد الطلب

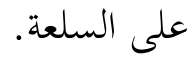

4- ذكر مصادر أخرى تؤثر في العرض مثل زيادة الناتج والاستيراد الخارجي.

5- استعمل لفظ الظلم عند الحديث عن التدخل المفتعل في قوى السوق، وذلك لربط النواحي الحياتية

بالثواب والعقاب ورضى الله سبحانه وتعالى والخوف من عقابه، مما يجعل البائع أو المستهلك يستشعر رقابة الله في سره

$$
\text { وعلنه عند ممارسة البيع. }
$$

6- كان له مساهمة في متغيرات العرض والطلب، إذ ربط بين زيادة الطلب وقلة العرض عند تحديد الأسعار.

$$
\text { 7- أدخل عوامل غيبية غير معروفة في آلية السوق من عند الله لا يعلمها إلا هو سبحانه وتعالى }
$$

8- أخذ بالعامل النفسي في العرض واطلب وذلك أن الناس عندما يقل عرض مادة يخافون من انقطاعها،

$$
\text { فيتهافتون على شرائها خوفاً من فقدانها من الأسواق. }
$$

$$
\begin{aligned}
& 40 \text { الوكس: النقص. لسان العرب، مادة وكس ج6 ص ص257. }
\end{aligned}
$$

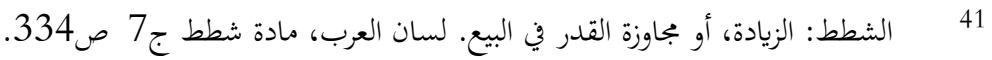

$$
\begin{aligned}
& 42
\end{aligned}
$$


9- كشف عن عامل آخر في قوى السوق غير العرض والطلب، وهو الرغبة في الحصول على الأرباح الفاحشة من خلال الاحتكار والحصر وتواطؤ الباعة والمشترين، مما يعيق قوى السوق في تحديد الأسعار.

10- أوضح خلو السوق الإسلامي من المعيقات التي تعيق عمل قانون العرض والطلب، مثل معرفة الباعة والمشترين بالأسعار، والمحاباة في البيع والشراء والاحتكارات، وتدخل الدولة القسري.

11- بيّن المؤثرات التي تؤثر في الرغبة "الطلب" والأسعار، وكر مها: أ- توفر البضاعة وكثرة عرضها. ب- كثرة الطلب على البضاعة.

ت- أهمية السلعة بالنسبة إلى المستهلك "ضرورية كانت أم كمالية". ث- وضع المشتري من حي قدرته الشرائية ومكانته المالية. ج- نوعية النقد المدفوع ومقدار قوته الشرائي. ح- قدرة المشتري على الوفاء بالالتزام وما يترتب عليه.

التسعير يقصد به عملية تقدير الدولة أو ولي الأمر أثماناً معينة ومحددة للسلع والخدمات، بحيث يلتزم بها البائع والمشتري، ولا يجوز لمما الزيادة عليها أو إنقاصها تحت طائلة العقوبة، 43 وعرّفه شيخ الإسلام ابن تيمية بأنه إلزام التجار بقيمة المثل حيث يقول، (ولا معنى للتسعير إلا إلزامهم بقيمة المثل). 44

$$
\begin{aligned}
& 43
\end{aligned}
$$

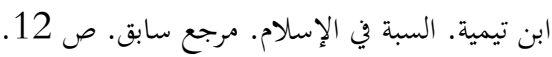


وعملية التسعير، إحدى معالم النظم الاقتصادية التي تميز بين هذه الأنظمة، فمثلاً النظام الرأسمالي تتحدد فيعه الأسعار حسب قوى السوق "العرض والطلب"، دون تدخل من الدولة في سوق كاملة حرة خالية من الاحتكارات، وتتوافر فيه المنافسة والمعلومات، ولا يضبطها إلا البائع فإنه يسعى لتحقيق أقصى ربحية له، والمشتري سعى لتحقيق وتعظيم منافعه ضمن دخل، أما في النظام الاشتراكي فالتسعير يتم عن طريق أجهزة الدولة التي تحددها ضمن إطار التخطيط المركزي، ولا يجكمها إلا سياسات وأهداف الحزب، 45 وفي الإسلام اختلف الفقهاء، حول مسألة التسعير بين مجيز لها ومانع مفصل في الموضوع على النحو التالي:46 1- جمهور الفقهاء ومنهم أبو حنيفة 47 والشافعي 48 وأمد:49 فهولاء، لا يجيزون التسعير ويعتبرون البيع في حالة التسعير إكراهاً ولا يصح هذا البيع.

2- بعض المالكية، 50 ولايجيزون التسعير، ولكن إذا خالف احد السعر بالزيادة أو النقصان فإنه يجبر على سعر السوق أو يخزج من السوق، وبعضهم رأى الإجبار والإخراج في حالة الزيادة في السعر جدون النقصان. 3- متأخرو الحنفية 51 أجازوا التسعير في حالات الأقوات ووقت الضرورة، وإذا كان ارتفاع الأسعار فاحشاً. 4- بعض المالكية52 وبعض الشافعية53 وابن تيمية وتلميذه ابن القيم، 54 يجيزون التسعير العادل في الأموال والأعمال إذا احتاج الناس لذلك. - ملك.

$$
\begin{aligned}
& 45
\end{aligned}
$$

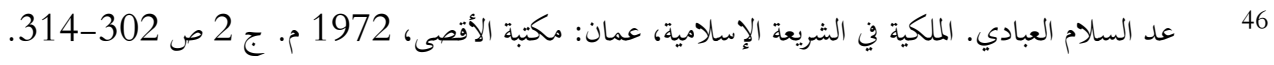

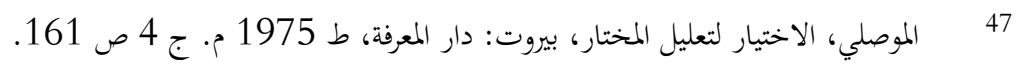

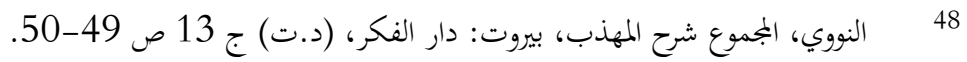

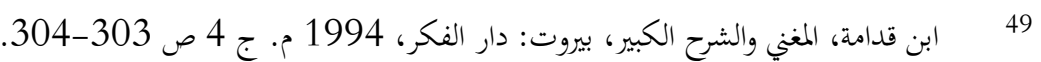

50 50

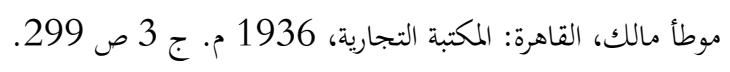

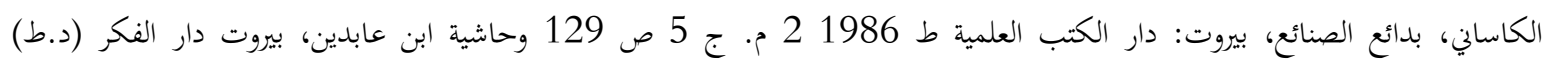

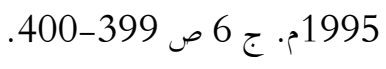

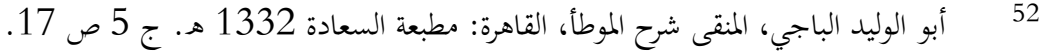

$$
\begin{aligned}
& 53 \\
& \text { ابن القيم، الطرق الحممية في السياسة الشرعية، تحقيق مُمد حامد الفقي، بيروت: دار الكتب العلمية (د.ت) ص } 254 .
\end{aligned}
$$




$$
\text { 5- سعيد بن المسيب وربيعة بن عبد الرحمن } 55 \text { يجيزان التسعير مطلقاً. } 56
$$

وقد استدل مانعو التسعير بجملة من الأدلة منها: 1- مارواه أنس قال، غلا السعر على عهد رسول الله صلى الله عليه وسلم فقالوا: يا رسول الله لو سعّرت، فقال، "إن الله هو القابض الباسط الرازق المسعّر، وإين لأرجو أن ألفى الله عز وجل ولا يطلبني أحد بمظلة ظلمتها إياه في دم ولا مال"، 57 ويقولون إن الرسول صلى الله عليه وسلك أوضح أن التسعير ظلم ومظلمة وحرام لاييجوز، ولو كان التسعير جائزاً لأجازه لهم رسول الله صلى الله عليه وسلم، وفي رواية أخرى ع أبي هريرة قال: جاء رجل فقال: يا رسول الله سعر، فقال: بل أدعو الله، ثم جاء آخر فقال: يا رسول الله سعّر فقال: "بل الله يخفض ويرفع". 58 2- يرون الناس مسلطون على أمواهم ولا تؤخذ غم إلا عن طيب نفس وفي المواضع اللازمة، وهذا موضع غير لازم، وأن التسعير حجر في الأموال، والحجر على المسلم الحر العاقل البالغ لايجوز. 3- يرون أن الإمام مأمور برعاية مصالح الناس بشكل عام، بائعين ومشترين فلا يمكن طرفاً من طرف، بل يترك الطرفين يجتهدان في تحقيق مصالحهما بالسعر الذي يتفقان عليه.

4- ويرون كذلك أن التسعير بسعر معين وإجبار الباعة عليه يتعارض مع قوله تعالى، وله إلا أن تكون بتحارة عن

$$
\text { تراض منكمي } 59
$$

$$
\text { 55 أبو الوليد الباجي، المنقى شرح الموطأ، مرجع سابق. ج } 5 \text { ص } 18 .
$$

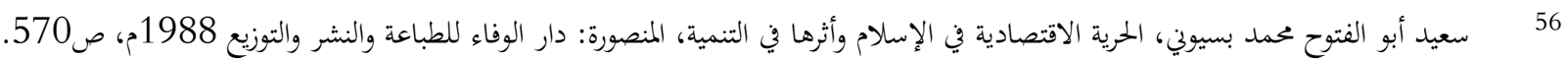

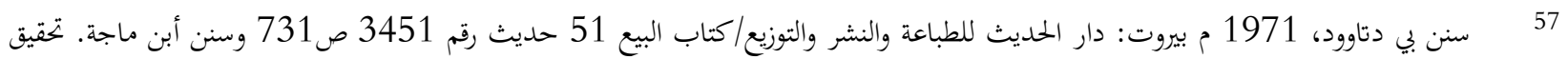

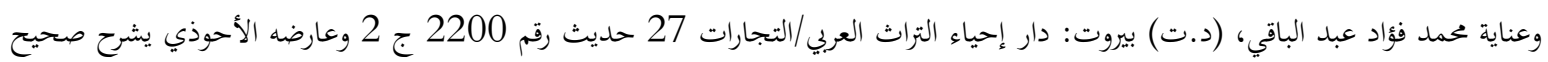

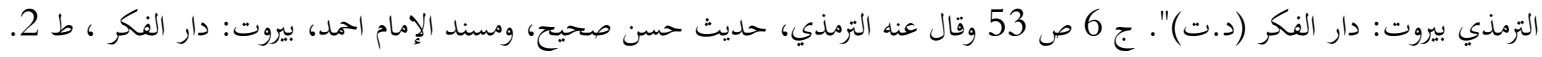

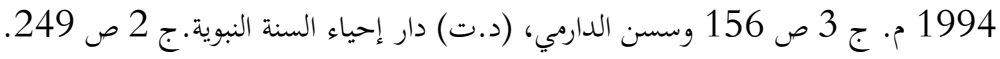

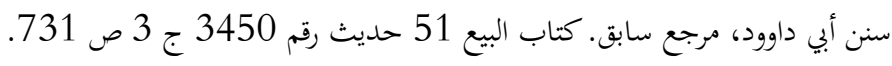


5- قالوا إن التسعير يسبب الغلاء، لأن الجالبين إذا علموا بالتسعير يبتعدون عن السوق مما يقلل عرض السلع فيرتفع سعرها، ومن عنده البضاعة يخزّها ولا ينزها إلى السوق، فيرتفع كذلك السعر، وهذا إضرار بالبائع والمشتري. وأصحاب المذهب الثاني، استدلوا بما روي عن سعيد بن المسيب أن عمر بن الخطاب رضي الله عنه علم بقدوم قافلة زبيب، وقد مر بحاطب بن أبي بلتعة وهو يبيع زبيباً بالسوق، وكان يبيع بسعر أقل، فقال عمر بن الخطاب، إما أن تزيد في السعر وإما أن ترفع من سوقنا، 60 فرفع الأسعار يؤدي إلى الإضرار بالمسلمين، وخفضها يؤدي إلى الإضرار بأهل السوق، مما يؤدي إلى الخصومات والشغب.

أما أصحاب المذهب الرابع ومنهم ابن تيمية فقد استدلوا بأدلة ليردوا على أدلة الفريق الأول على النحو التالي:

1- إن التسعير أمر بالواجب والمعاقبة على تركه، فكل شخص وجب عليه البيع بثمن المثل وامتنع أن يبيع إلا بأكثر منه، يؤمر بالواجب ويعاقب على تركه، يقول ابن تيمية، و(أما إذا امتنع الناس من بيع ما يجب عليهم بيعه فنا يؤمرون بالواجب ويعاقبون على تركه، وكذلك من وجب عليه أن يبيع بثمن المثل فامتنع أن يبيع إلا بأكثر منه، فهنا يؤمر بما يجب عليه ويعاقب على تركه بلا ريب).

2-ثبت عن رسول الله صلى الله عليه وسلكم أنه أمر بتسعير حصة الشريك في العبد عند العتق، فتقدير الرسول صلى الله عليه وسلم للثمن إجازة له، يقول ابن تيمية، (وأما من تعين عليه أن يبيع، فكالذي كان النبي صلى الله عليه وسلم قدر له الثمن الذي يبيع به ويسعر عليه، كما في الصحيحين عن النبي صلى الله عليه وسلم أنه قال، "من اعتق شريكاً له في عبد، وكان له من المال ما يبلغ ثمن العبد قوّم عليه قيمة عدل لا وكس ولا شطط، فأعطى شركاءه حصصطم وعتق عليه العبد"، 62 فهذا لما وبج عليه أن يملك شريكه عتق نصيبه الذي لم يعتقه ليكمل الحرية في العبد، قدّر عوضه بأن يقوّم جميع العبد قيمة عدل ولا وكس ولا شطط، ويعطى قسطه من القسمة فإذا كان الشارع يوجب إخراج الشيء من ملك مالكه بعرض المثل لحاجة الشريك إلى إعتاق ذلك، وليس للمالك المطالبة بالزيادة على نصف القيمة، فكيف بمن كانت حاجته أعظم من الحاجة إلى إعتاق ذلك النصيب، مثل حاجة المضطر إلى

$$
\begin{aligned}
& 60 \text { أبو الوليد الباجي، المتقى شرح الموطأ، مرجع سابق. ج } 4 \text { ص ص } 17 . \\
& 61
\end{aligned}
$$

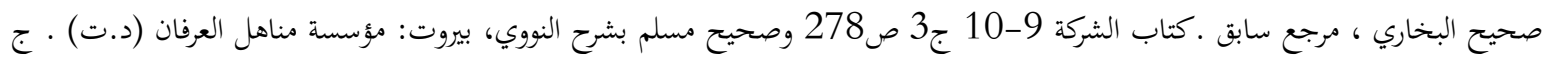


الطعام واللباس وغير ذلك، وهذا الذي أمر به النبي صلى الله عليه وسلك من تقويم الجميع بقيمة المثل هو حقيقة التسعير).

3- في حق الشفعة للشريك في الملك، له الق في أخ الجزء المباع من يد المتملك وبنفس الثمن الذي اشتراه به،

يقول ابن تيمية، (وكذاك يجوز للشريك أن ينزع النصف المشفوع من يد المشتري بمثل الثمن الذي اشتراه به، ولا بزيادة للتخلص من ضرر المشاركة والمقاسمة، وهذا ثابت بالنسبة المستفيضة وإجماع العلماء، وهذا إلزام له بأن يعطيه ذلك المن، لا بزيادة لأجل تحصيل مصلحة التكميل لواحد، فكيف بما هو أعظم من ذلك ولم يكن له أن يبيعه للشريك بما شاء، بل ليس له أن يطلب من الشريك زيادة على الثمن الذي حصل له به).64

4-استدلوا كذلك بحيث سمرة بن جندب، إذ إن الرسول صلى الله عليه وسلم طلب من صاحب الشجرة قبول ثمنها أو أن تقلع، يقول ابن تيمية، (وفي السنن أن رجاً كانت له شجرة في أرض غيره، وكان صاحب الأرض يتضرر بدخول صاحب الشجرة، فشكا ذك إلى النبي صلى الله عليه وسلم، فأمره أن يقبل منه بدلها أو يتبرع له بها، فلم يفعل، فأذن لصاحب الأرض في قلعها، وقال لصاحب الشجرة، "إنما أنت مضار"، 65 فهنا أوجب عليه إذا لم يتبرع كها أن يبيعها، فدل على وجوب البيع عند حاجة المشتري، وأين حاجة هذا من حاجة عوم الناس إلى الطعام؟). 66 5- إذا كان في الحق العام أجيز وضع ثمن والإجبار عليه، فالحق الشخصي أولى أن يحدد له عند الضرورة سعر ويجبر عليه، يقول ابن تيمية، (والمقصود هنا أنه إذا كانت السنة قد مضت في واضع بأن على المالك أن يبيع ملاه بثمن مقدر، إما بثمن المثل وإما بالثمن الذي اشتراه به لم يحرم مطلقاً تقدير الثمن، ثم إن ما قدّر به النبي صلى الله عليه وسلم في شراء نصيب شريك المعتق هو لأجل تكميل الحرية، وذلك حق الله، وما احتاج إليه الناس حاجة عامة، فالحق فيه لله، ولها يجعل العلماء هذه حقوقاً لله تعالى وحدوداً لله، بخلاف حقوق الآدميين وحدودهم، وذلك مثل حقوق المساجد، وممال الفيء، والصدقات، والوقف على أهل الحاجات، والمنافع العامة، ونو ذلك وحاجة المسلمين إلى الطعام واللباس، وغير ذلك من مصلحة عامة ليس الحق فيها لواحد بعينه، فتقدير الثمن فيها بثمن المثل على من

$$
\begin{aligned}
& 63 \text { ابن تيمية، الحسبة في الإسلام، مرجع سابق. ص } 64
\end{aligned}
$$

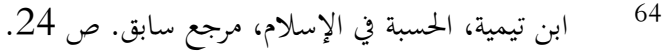

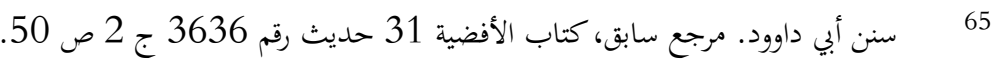

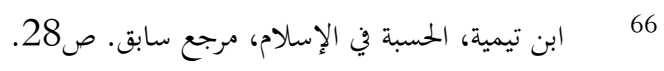


وجب عليه البيع أولى من تقديره لتكميل الحرية،لكن تكميل الحرية وجب على الشريك المعتق، فلو لم يقدر فيها الثمن لتضرر بطلب الشريك الآخر ما شاء و، وهنا عموم الناس عليهم شراء الطعام والثياب لأنفسهم، فلو مُكّن من يحتاج إلى سلعته أن لا يبيع إلا بما شاء لكان ضرر الناس أعظم).

6-رد شيخ الإسلام على استدلال المانعين بحديث صلى الله عليه وسلم، عندما طلب منه التسعير بحجة أن هذا قضية خاصة ومعينة وليس حكماً عاماً، ومن يحتج به فقد أخطأ، يقول، (ومن منع التسعير مطلقاً محتجاً بقول النبي صلى الله عليه وسلم، "أن الله هو المسعر القابض الباسط، وأني لأرجو أن ألقى الله وليس أحد منكم يطالبني بمظلمة في دم ولا مال"68 فقد غلظ، فإن هذه قضية معينة ليست لفظاً عاماً، وليس فيها أن أحداً امتنع من بيع يجب ليج عليه أو عمل يجب عليه، أو طلب في ذلك أكثر من عوض المثل، ومعلوم أن الشيء إذا رغب الناس في المزايدة فيه، فإذا كان صاحبه قد بذله كما جرت به العادة ولكن الناس تزايدوا فيه، فهنا لا يسعر عليهم)، 69 ويف وضع المدينة زمن رسول الله صلى الله عليه وسلم كزيادة في الإيضاح، مبنياً أنه كان لها خصوصية تنبع من كون الباعة من التجار الخارجيين وليسوا من أهل المدينة، إضافة إلى أفم كانوا يعيشون حالة جهاد وحرب، فأي تسعير والحالة هذه سيضر باقتصاد المدينة، يقول، (والمدينة كما ذكرنا، إنما كان الطعام الذي يباع فيها غالباً من الجلب، وقد يباع فيها شيء

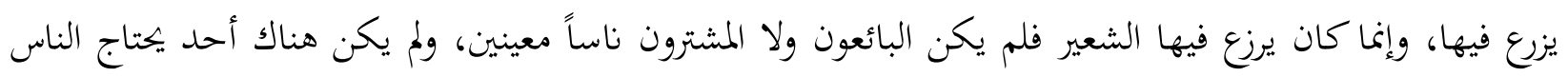
إلى عينه أو إلى ماله ليجبر على عمل أو على بيع، بل المسلمون كلهم من جنس واحد كلهم يجاهد في سبيل الله، ولمك يكن من المسلمين البالغين القادرين على الجهاد إلا من يخرج في الغزو، وكل منهم يغزو بنفسه اله أو بما أعطاه من الصدقات أو الفيء أو ما يجهزه بع غيره، وكان إكراه البائعين على أن لايبعوا سلعهم إلا بمن معين إكراهاً بغير

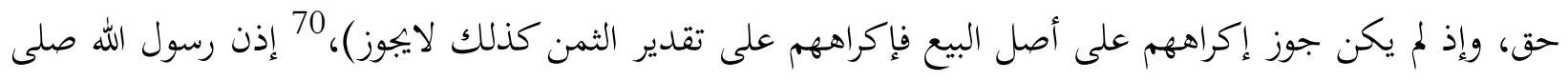
الله عليه وسلم لم يسعر عندما طلب منه ليس لكون التسعير حراماً، ولكن لعدم الحاجة إليه، 71 وقد كون هناك أسباب أخرى لرفض رسول الله صلى الله عليه وسلك للتسعير، مثل رغبته في ترسيخ حرية السوق في نفوس المسلمين،

$$
\begin{aligned}
& 67 \\
& 68 \\
& 69 \\
& 70 \\
& 71
\end{aligned}
$$


وتشجيع مبدأ المبادرة الفردية في الاقتصاد الإسلامي، وليس كلما حدث طارئ نلجأ إلى التدخل والتسعير، 72 أو قد يكون ارتفاع الأسعار ناشئاً عن العرض والطلب وارتفاع تكاليف إنتاج السلع أو قلة عرضها، ولذلك استبط

$$
\text { الفقهاء³ من هذا الحديث عدة أمور تؤيد ما ذهب إليه ابن تيمية منها: }
$$

أ- أن سب ارتفاع السعر في المدينة على زمن رسول الله صلى الله عليه وسلم كان أمراً طبيعياً نابعاً من العرض

$$
\text { ب- أن هذا الارتفاع أمر عارض يزول بزوال سببه. }
$$

ت- أن رسول الله صلى الله عليه وسلم لم يسعر شعوراً منه بان الأسعار ستعود إلى وضعها الطبيعي بعد زوال السبب، وهذا ما حصل فعلاً، إذ بعد قدوم الجلب عادت الأسعار لسابق عهدها.

ث- أن التسعير في هذه الحالة ظلم للبائعين وإكراهُ لمم بغير حق، لهم الأسعار لم ترتفع بسبهم، وهذا حرام لم يقره رسول الله صلى الله عليه وسلم.

7- كما يقول ابن تيمية فإن الشافعي وأبا حنفية اللّذين يمنعان التسعير يجيزانه في حالات، يقول، (ولها قال الفقهاء إذا اضطر الإنسان إلى طعام الغير كان عليه بذله له بثمن المثل، فيجب الفرق بين من عليه أن يبيع وبين من

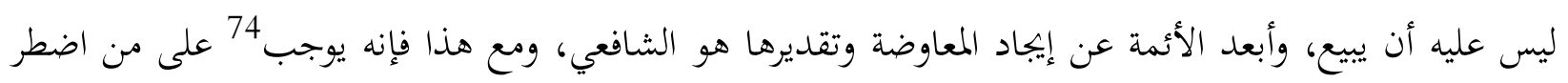
الإنسان إلى طعامه أن يعطيه بثمن المثل وقال أصحاب أبي حنيفة75 لا ينبغي للسلطان أن يسعر على الناس إلا إذا تعلق به حق ضرر العامة، فإذا رفع إلى القاضي أمر المحتكر ببيع ما فضل عن قوته وقوت أهله على اعتبار السعر في

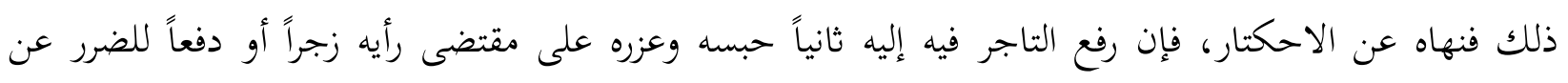

$$
\begin{aligned}
& 72
\end{aligned}
$$

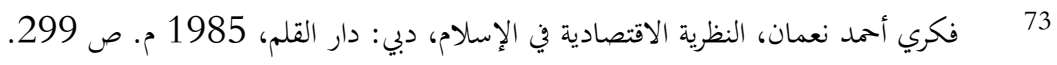

$$
\begin{aligned}
& 74
\end{aligned}
$$

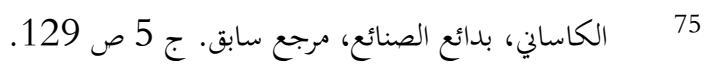


الناس، فإن كان أرباب الطعام يتعدون ويتجاوزون القيمة تعدياً فاحشاً وعجز القاضي عن صيانة حقوق المسلمين إلا بالتسعير، سعر حيئذ بمشورة أهل الرأي والبصيرة وإذا تعدى احد بعد ما فعل ذلك أجبره القاضي). ويميل الباحث إلى رأي شيخ الإسلام ابن تيمية للأسباب التالية:

1-أن رسول الله صلى الله عليه وسلم أوضح في معرض حديثه عندما طلب منه التفسير، أن الزيادة التي حصلت في السعر لم تكن من تصرفات الباعة والمشترين المفتعلة وتدهم غير المشروع في قوى السوق، وإنا مردها إلى قلة المعروض من البضاعة لظروف عادية، فعندها يضيف الرفع والحفض في الأسعار لله سبحانه وتعالى، ومع ذلك إن الخلل الذي حدث مرده إلى قوى السوق والأمور الطبيعية، وليس إلى تدخل البشر في السوق، وقد حصل أن حدث خلل في السوق بفعل الشر، فتدخل رسول الله صلى الله عليه وسلم ونبه إليه، مثل منعه للاحتكار وتلقي الركبان وبيع الحاضر للبادي، وأيضاً عدم تسعير رسول الله صلى الله عليه وسلم في هذه الحالة وفي الظروف التي كانت تعيشها المدينة، يدل على بعد نظر رسول الله صلى الله عليه وسلم، فالمدينة في حالة حرب وجهاد، والصحابة رضوان الله عليهم فرسان في النهار وعُبّاد في الليل، وأمر التجارة معتمد على الجالبين، فلو سعّر لحدث خلل من قبل الجالبين إذ قد يحجمون عن القدوم إلى سوق المدينة، وهذه كارثة اقتصادية للمسلمين.

2-أن ما احتج به المانعون من أن التسعير حجر، والحجر لاييجوز، فهذه فقاعدة شرعية منة ضم قواعد متعاضدة مع بعض الفقهاء وتعمل جنباً إلى جن مثل "لا ضرر ولا ضرار"، و"منع الضرر"، و"المصلحة العامة تقدم على المصلحة الخاصة"، و"الضرر الأشد يزال بالضرر الأخف"، وكذلك فإن العدل أساس الإسلام، وهو عام لجميع أفراد المجتمع دون فئة معينة للباعة والمشترين، فإذا لم يسعر أطلق العنان للباعة وظلم المشترين.

وينطل ابن تيمية في حديثه عن التسعير من قاعدة أن الأصل هو حرية السوق، وترك الأسعار تتجدد عن طريق قوى السوق ولا يتدخل إلا عند الضرورة، 77 ولذلك نراه يقرّ في بداية حديثة أن الناس مسلطون على أموالهم، ولا يحق لأحد أن يأخذها منهم إلا عن طيب نفس، فيقول، (وله أقول لأن الناس مسلطون على أموالهم ليس لأحد أن

$$
76 \text { ابن تيمية، الحسبة في الإسلام، مرجع سابق. ص 26-27. }
$$


يأخذها أو شيئاً منها بغير طيب أنفيهم، إلا في الواضع التي تلزهم)، 78 ثم يؤكد على أنه إذا كانت الأسعار تتحدد وَفْقَ العرض والطلب، ولا يوجد تدخل فيها وسارت أمور الناس لاحاجة للتسعير، فيقول، (وإذا كانت حاجة الناس تندفع إذا عملوا ما يكفي الناس بحيث يشترى إذ ذاك بالثمن المعروف لم يحتج إلى تسعير، وأما إذاكانت حاجة الناس رل لا تندفع إلا بالتسعير العادل سعّر عليهم تسعير عدل ولا وكس ولا شطط) 79. ويقسّم رحمه الله التسعير إلى نوعين:

$$
\text { 1-ظلم مخرم، وذلك عندما يتم إكراههم بغير حق على سعر لايرضونه }
$$

2-عدل جائز، وذكك عندما يتضمن العدل بين الناس وإكراههم على ما يجب عليهم بثمن المثل

فيقول، (ومن هنا يتبين أن السعر منه ماهو ظلم لاييجز، ومنه ماهو عدل جائز، فإذا تضمن ظلم الناس وإكراههم بغير حق على البيع بثمن لايرونه، أو منعهم مما أباحه الله لهم، فهو حرام وإذا تضمن العدل بن الناس مثل إكراههم على ما يجب عليهم من المعاوضة بمن المثل، ومنعهم مما يحرجم عليهم من أخذ زيادة على عوض المثل فهو جائز بل واجب). 80 وذكر رفض رسول الله صلى الله عليه وسلم للتسعير وبدرجه تحت النوع الأول قائلاً، (فأما الأول فمثل ما روى أنس قال، غلا السعر على عهد رسول الله صلى الله عليه وسلم فقالوا: يا رسول الله لو سعّرت، فقال، إن الله هو القابض الباسط الرازق المسعر، وإني لأرجو أن ألقى الله ولا يطلبن أحد بمظلمة ظلمتها إياه في دم ولا مال" 81828. ثم يبين حالة النوع الأول وهي عندما تتحدد الأسعار حسب قوى السوق دونما تدخل من أحد فيقول، (فإذا كان الناس يبيعون سلعهم على أوجه المعروف من غير ظلم منهم، وقد ارتفع السهر إما لقلة الشيء وإما لكثرة

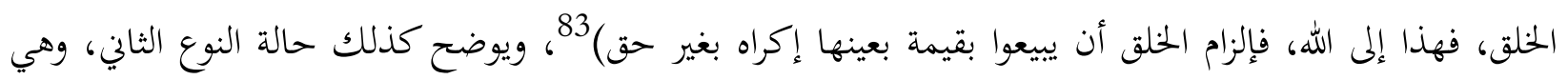
ارتفاع الأسعار ونزولها بسبب تدخل البشر في قوى السوق، يقول، (وأما الثاني فمثل أن يمتنع أرباب السلع عن بيعها مع ضرورة الناس إليها، إلا بزيادة على القيمة المعروفة، فهنا يجب عليهم بيعها بقيمة المثل، ولا معنى للتسعير إلا

$$
\begin{aligned}
& 78 \text { ابن تيمية، الحسبة في الإسلام، مرجع سابق. ص } 21 . \\
& 79 \\
& 80 \\
& 81 \\
& 82 \\
& 83
\end{aligned}
$$


إلزامهم بقيمة المثل، فيجب أن يلتزموا بما ألزمهم الله به)"84، فارتفاع الأسعار في الحالة الأولى أمر طبيعي، لذلك لا تدخل فيه، أما في الحالة الثاني فكان السبب تحكم الباعة في العرض مع أهمية السلعة وضرورتا وها يرفع السعر وعندها من الضرورة التدخل للتسعير 85.

\section{والتسعير الأول الظالم له أضرار اقتصادية تحدث عنها شيخ الإسلام ابن تيمية ومنها:}

1-فساد الأسعار، إذ لو بقيت الأسعار على حالها حسب قوى السوق، تكون معبرًاً حقيقياً عن الرغبة

الحقيقية والطلب الحقيقي للمشترين، وعن العرض الحقيقي للباعة، أما إذا تدخلت الدولة وسعرت سعراً غير عادل فإن ذلك سيضر بالأسعار ويفسدها ولاسيّما عند انتشار الأسواق السوداء وتباين الأسعار.

2-اختفاء الأقوات، إذ قد يلجأ الباعة إلى إخفاء السلع لبيعها في السوق السوداء بالسعر الذي يريدون، ولا يتقيدون بالسعر الذي حددته الدولة له طمعاً في تحصيل أكبر قدر من الربح.

3-إتلاف أموال الناس، فإذا حددت سعراً فقد يتقلص طلب المشترين وتكسد السلع ولا تجد من يشتريها

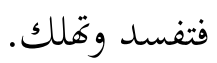

4-خروج الباعة من السوق، إذا سعّرت الدولة على التجار تسعيراً غير عادل، فقد يؤدي ذلك إلى خسارة

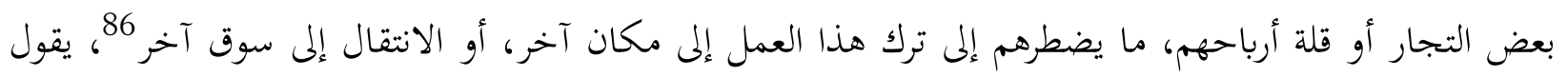
ابن تيمية، (وإذا سعّر عليهم من غير رضا بما لا ربح لهم فيه أدى ذلك إلى فساد الأسعار وإخفاء الأقوات وإتلاف أموال الناس) 87، ويقول فيما ينقله عن الإمام مالك، (قال: إذا سعّر عليهم قدر ما يرى من شرائهم فلا بأس به ولكن رصن

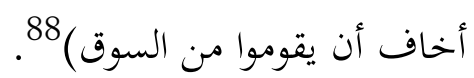

$$
\begin{aligned}
& 84 \\
& 85
\end{aligned}
$$

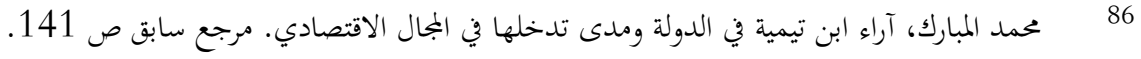

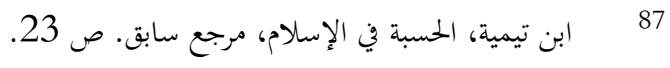

$$
\begin{aligned}
& 88
\end{aligned}
$$


ولذلك نجد ابن تيمية -رجمه الله- يذك بعض الحالات التي يجوز لولي الأمر أو للدولة التدخل عندها وتحديد السعر ويكر منها:

1-حاجة الناس إلى السلعة، فإذا احتاج الناس إلى سلعة ما، وخوفاً من استغلال الباعة لهذه الحاجة يجوز التسعير، وذلك كعلاج لحاجة عامة89، ومنعاً للظلم ومسايرة لقاعدة الضرورات تبيح المخظورات، 90 يقول ابن تيمية، (ولما كان لولي الأمر أن يكره الناس إلى بيع ما عندهم بقيمة المثل عند ضرورة الناس إليه، مثل من عنده طعام لايحتاج

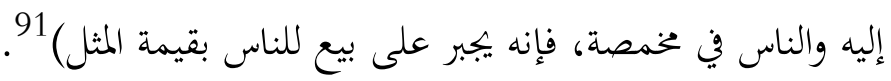

2- الاحتكار، وهو كما عرفه ابن تيمية، (هو الذي يعمد إلى شراء ما يحتاج إليه الناس من الطعام فيحبسه

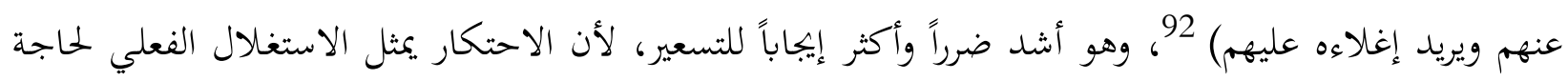
الناس إلى السلعة، 93، وحتى ابن تيمية يرى الحجر على المحتكر دفعاً للضرر العام الذي يمكن أن يلحق بالناس عند

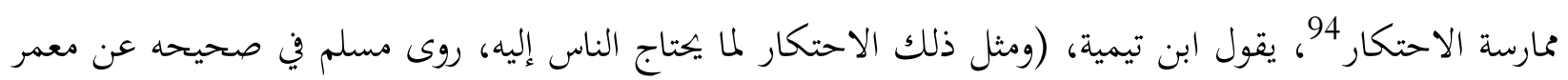
بن عد الله أن النبي صلى الله عليه وسلم قال، "لا يحتكر إلى خاطئ"95، فإن المتكر هو الذي يعمد إلى شراء ما

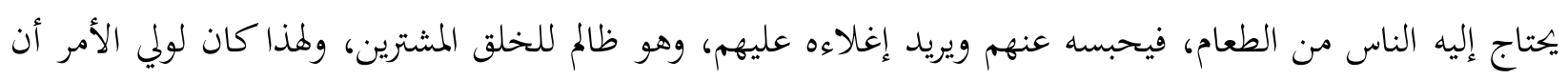
يكره الناس على بيع ما عندهم بقيمة المثل عند ضرورة الناس إليه) 96.

3-حالة الحصر، أي جعل بيع سلعة معينة أو شرائها، غخصوص بأناس معينين، ويمنع غيرهم م بيعها أو شرائها وهو ما يطلق عليه حديثاً الموزع المعتمد 97، أو حق امتياز بيع السلع 98، وهو أمر لجأت إليه الدول قديماً وتلجأ إليه

$$
\begin{aligned}
& 89
\end{aligned}
$$

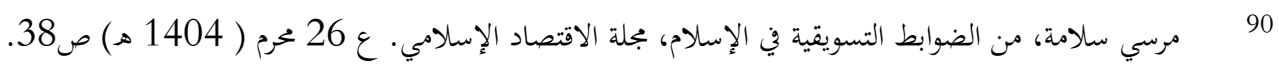

$$
\begin{aligned}
& 91 \\
& 92 \\
& 93 \\
& 94 \\
& 95
\end{aligned}
$$

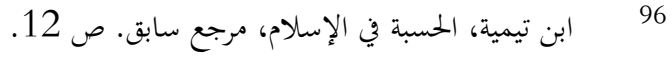

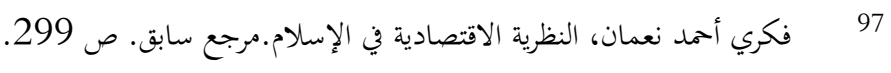

$$
\begin{aligned}
& 98
\end{aligned}
$$


حديثاً في بعض المواد والظروف والأحوال، وهذه الحالة يتعرض فيها المشتري إلى تسلط البائع وتحكمه، كون هذه المادة لاتوجد إلا عنده ومرد المشتري إليه، يقول ابن تيمية: (وأبلغ من هذا أن يكون الناس قد التزموا أن لا يبيع الطعام أو غيره إلا أناس معروفون، لاتباع تلك السلع إلا لمم ثم يبيعوها هم، فلو باع غيرهم ذلك منع إما ظلماً لوظيفة تؤخذ من البائع وإما غير ظلم، لما في ذلك من الفساد، فها هنا يجب التسعير عليهم، بحيث لا يبيعون إلا بقيمة المثل ولا يشترون أموال الناس إلا بقيمة المثل بلا تردد في لك عند أحد من العلماء، لأنه إذا كان قد منع غيرهم أن يبيع ذلك النوع أو يشتريه، فلو سوغ لمم أن يبيعوا بما اختاروا أو اشتروا بما اختاروا كان ذك ظلماً للخلق من وجهين؛ ظلماً للبائعين الذين يريدون بيع تلك الأموال، وظلماً للمشترين منهم، والواجب إذا لم يكن دفع جميع الظلم أن يدفع الممكن منه، فالتسعير في مثل هذا واجب بلانزاع، وحقيقة إلزامهم أن لايبيعوا أو لا يشتروا إلا بثمن المثل، وهذا واجب في مواضع كثيرة من الشريعة، فإنه كما أن الإكراه على البيع لايجوز إلا بحق يجوز الإكراه على البيع بحق في مواضع)

4-حالة تواطؤ البائعين وتآمرهم على المشترين طمعاً في الربح الفاحش، أو تواطؤ المشترين في حال محدوديتهم، وهي شبيهة بما يطلق عليه اليوم "الكارتل والترست"، و"الكارتل" مصطلح لاتيني يعني الميثاق، ويقصد هـ اتفاق "تواطؤ" بين عدة شركات أو مشروعات كبيرة كل منها ذات إدارة مستقلة، وذلك من أجل الحد من المنافسة أو إلغائها، فتقاسم الإنتاج والأسواق وتتفق على سياسية الأسعار وتسيطر على الأسواق"100، والترست "مصطلح لاتيني يعني الاتفاق، ويقصد به انصهار "اندماج" عدة شركات في شركة واحدة قابضة ذات إدارة موحدة"101، وهذه الهيئات الاقتصادية "الكارتل والترست" تشكل خطراً في العصر الحديث كون الحكومات لا تستطيع ضبطها، مما يجعل المواطن والمستهلك هو الضحية والفريسة السهلة لها، يقول ابن تيمية، (ولذا منع غير واحد من العلماء كأبي حنيفة102 وأصحابه القَسّام الذين يقسمون العقار وغيره بالأجر أن يشتركوا والناس محتاجون إليهم فمنع البائعين الذي لئي تواطؤا على أن لايبعوا إلا بثمن قدروه أولى، وكذلك منع المشترين إذ تواطؤا على أن يشتركوا، فإغم إذا اشتركوا فيما

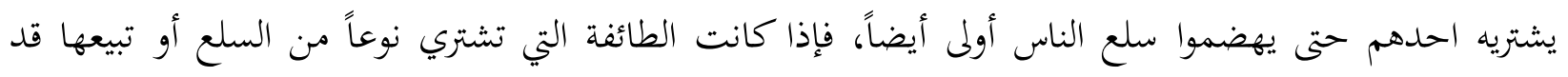

$$
\begin{aligned}
& 99 \\
& 100 \\
& 101 \\
& 102
\end{aligned}
$$


تواطأت على أن يهضموا مايشترونه، فيشترونه بدون ثمن المثل المعروف ويزيدون ما يبيعون بأكثر من الثمن المعروف، وينمون ما يشترونه، كان هذا أعظم عدواناً من تلقي السلع ومن بيع الحاضر للبادي ومن النجس، ويكونون قد اتفقوا على ظلم الناس، حتى يضطروا إلى بيع سلعهم وشرائها بأكثر من ثمن المثل، والناس يحتاجون إلى ذلك وشرائه، وما احتاج إلى بيعه وشرائه عموم الناس فإنه يجب أن لا يباع إلا بثمن المثل إذا كانت الحاجة إلى بيع وشرائه عامة) 103. وهذه لفتة طيبة من شيخ الإسلام في حديثه عن تواطؤ المشترين إذ يحافظ على مصلحة البائع عندما يتواطأ ويتفق المشترون من أجل الضغط على البائع لحمله على البيع بالسعر الذي يريدونه، والذي قد لا يمثل الالتقاء الحقيقي لرغبة الطلب والعرض، ولا يمثل سعر قوى السوق مما يلحق ضرراً بالتجار خاصةً وبالاقتصاد عامةً 104.

5-حالة امتناع أرباب السلع الضرورية عن بيعهام105، فإذا كانت السلعة ضرورية وامتنع البائع عن بيعها، فهنا لولى الأمر إجباره وتحديد سعر لبيعها، يقول ابن تيمية، (وأما الثاني فمثل أن يمتنع أرباب السبع من بيعها، مع ضرورة الناس إليه إلا بزيادة على القيمة المعروفة، فهنا يجب عليهم بيعها بقيمة المثل ولا معنى التسعير إلا إلزامهم بقيمة المثل، فيجب أن يلتزموا بما ألزمهم الله به) 106.

6-حالة الجهاد والحروب والكوارث، حيث تنظم أسواق بع السلاح ومستلزمات الحرب والجهاد، لأن الطلب سيزداد عليها، وخوفاً من ارتفاع أسعارها يسعّر عليهم، يقول ابن تيمية، (وأما في الأموال فإذا احتاج الناس إلى سلاح للمجاهد على أهل السلاح أن يبيعوه بعوض المثل، ولا يمكّنون من أن يحبسوا السلاح حتى يتسلط العدو أو يبذل لهم من الأموال ما يختارون فإذا وجب عليه أن يجاهد بنفسه وكماله، فكيف لا يجب عليه أن يبيع ما يمتاج إليه في الجهاد بعوض المثل 107.

أما عن كيفية التسعير عند الحاجة إليه، فد بيّن، رحمه الله، أها تتم بأن يجتمع ولسي الأمر مع كبار تجار السوق وبحضور بعض العامة، منعاً لإعطاء التجار أسعار ومعلومات غير حقيقية، ثم يفاوضهم على السعر، هم طباعة وهو

$$
\begin{aligned}
& 103 \text { ابن تيمية، الحسبة في الإسلام، مرجع سابق. ص 13-14. }
\end{aligned}
$$

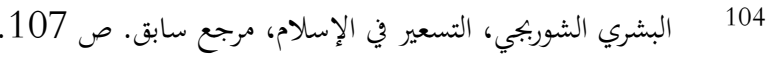

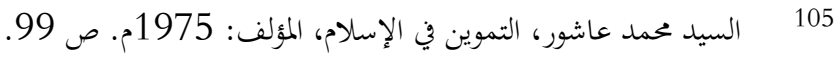

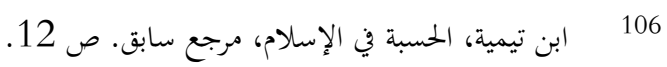

$$
\begin{aligned}
& 107
\end{aligned}
$$


كولي أمر ومثثل عن المشترين، حتى يتم التوصل إلى سعر يرضى به الباعة ويرضى به الإمام "المشترين" ويراعى في هذا

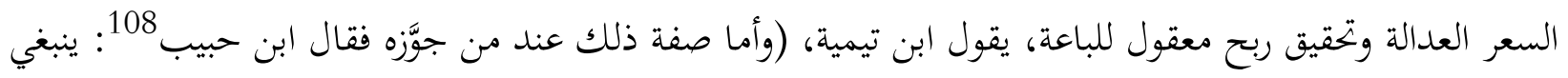
للإمام أن يجمع وجوه أهل سوق ذلك الشيء، ويحضر غيرهم استظهاراً على صدقهم فيسأهم كيف يشترون وكف رلف يبيعون، فينازهم إلى مافيه لهم وللعامة سداد حتى يرضوا ولا يجبرون على التسعير، ولكن عن رضا، قال: وعلى هذا

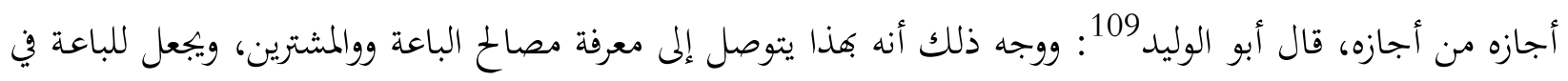
ذلك من الربح مايقوم بكم ولا يكون فيه إجحاف بالناس)

إذن فأساس التسعير عنده العدل وتحديد السعر الذي لاوكس فيه ولاشطط111، أي غير مرتفع بشكل يضرّ بالمشترين ولا متدن ير بالباعة، وهو الذي عبر عنه عند تقويم العبد المشترك من أجل السراية حيث يقول، (قوّم عليه قيمة عدل لا وكس ولاشطط)

ومن خلال استعراض نصوص ابن تيمية في التسعير نخلص إلى الشروط التالية في التسعير:

1-أن تنشأ حاجة عامة إلى السلع والخدمات مع ارتفاع أسعارها بشكل غير طبيعي يضر بالمستهلك ويجعل حياته صعبة وشاقة.

2-أن يكون سبب ارتفاع الأسعار تدخل التجار غير المشروع وتحكمهم في الأسعار، وليس ارتفاعاً بسبب

قوى السوق "العرض والطلب"113.

3-أن تسلك الدولة أو الحاكم كل السبل لحل المشكلة، فإذا استنفذت كل السب لإصلاح وضع السوق ولم تنجح، عندها لابد من التدخل للتسعير.

4-مراعاة معيار العدالة في التسعير، فتراعى مصلحة المشتري ومصلحة البائع 114.

$$
\begin{aligned}
& 108 \text { أبو الوليد الباجي، المنتقى شرح الموطا، مرجع سابق. ج } 5 \text { ص } 19 . \\
& 109 \\
& 110 \\
& 111 \\
& 112 \\
& 113
\end{aligned}
$$


وهذا ما نبه إليه شيخ الإسلام من انه إذا سعّر عليهم سعراً غير عادل، فسدت الأسعار واختفت الأقوات وأتلفت أموال الناس.

5-أن تأخذ الدولة أو ولي الأمر جميع الاحتياطات اللازمة لضمان سلامة وصول السلع إلى المواطنين بعد التسعير 115، لذلك أدرج ابن تيمية التسعير في كتاب "الحسبة في الإسلام"، على اعتبار أن الغلو في الأسعار والتلاعب فيها من المنكرات التي إزالتها من مسؤوليات المحتسب116، ويجبر البائع على البيع بالسعر الذي حُدِدة، ويعاقب تعزيراً كمل من امتنع عن التسعير ورفض ما أوجبه الحاكم أو المشرع عليه، فهو يأمر بالواجب الذي يعاقب على تركه 117، والإجبار هنا على الالتزام بالتسعير إذا توافرت فيه صفة العدل، وهذا ما قال فيه ابن تيمية، (وأما إذا امتنع الناس من بيع ما يجب عليهم بيعه فهنا يُؤمَرون بالواجب ويُعاقبون على تركه، وكلك من وجب عليه أن يبيع بثمن المثل فامتنع أن يبيع إلا بأكثر منه، فهنا يُؤمر بما يجب عليه ويُعاقب على تركه بلاريب)

6-استشارة ذوي الخبرة وأهل الاختصاص، وهذا يتم من خلال لجنة التسعير، والتي فيها أعضاء من كبار بتحار

السوق ووجوه البلد.

7-أن يكون التسعير ثمرة تفاوض مابين الباعة مثلين في وجوههم، وبين المشترين ممثلين بولي الأمر 119.

8-أن يراعى عند التسعير أنه ضرورة ويجب أن تقدر بقدرها، فهو حدد للضرورة ودفعاً للحرج، ولذلك يجب أن لا يكون إلا بقدر هذه الضرورة ولا تطلق له اليد والعنان 120.

ومن الأمور التي بحثها شيخ الإسلام مسألة البيع بأنقص من السعر، وهي منتشرة في العصر الحديث ولها الكثير من السلبيات 121، وتثير الكثير من الخصومات والشغب وتلحق بالتجار أضراراً كبيرة122، وقد تناول اختلافات

مركز الاقتصاد الإسلامي / تدخل الدولة في النشاط الاقتصادي في إطار الاقتصاد الإسلامي. القاهرة: الصرف الإسلامي الدولي للاستمار والتنمية 
الفقهاء حولها كمايلي، يقول: (وقد تنازع العلماء في التسعير في مسألتين، إحداهما إذا كان للناس سعر غال فأراد بعضطم أن يبيع بأغلى من ذلك، فإنه يمنع منه في السوق في مذهب مالك 123، وهل يمنع النقصان؟ على قولين لهم، وأما الشافعي 124 وأصحاب أحمد 125، كأبي حفص العكبري والقاضي أبي يعلى والشريف أبي جعفر وأبي الخطاب وبن عقيل وغيرهم فمنعوا من ذلك، واحتج مالك 126 بما رواه في موطئه عن يونس بن سيف عن سعيد بن المسيب أن عمر بن الخطاب مرّ بحاطب بن بلتعة وهو يبيع زبيباً له بالسوق، فقال له عمر: إما أن تزيد في السعر وإما أن ترفع

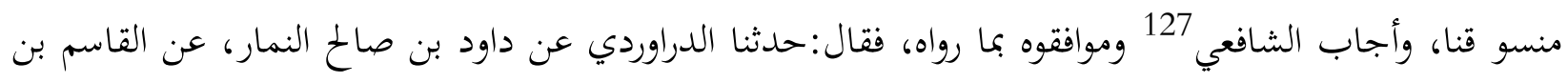
محمد، عن عمر انه مرَ بحاطب بسوق المصلى وبين يديه غرارتان فيهما زبيب، فسأله عن سعرهما، فسعّر له مدّين

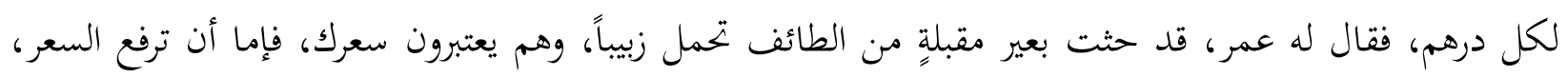
وغما أن تدخل زبيبك البيت فتبيعه كيف شئت، فلما رجع عمر حاسب نفسه، ثم أتى حطباً في داره فقال: إن الذي قلت لك ليس بمعرفة مني ولا قضاء، إنما هو شيء أردت به الخير لهل البلد، فحيث شئت فبع وكيف شئت فبع، وقال الشافعي 128، وهذا الحديث مقتضاه ليس بخلاف ما رواه مالك، ولكنه روى بعض الحسيث ولحيث أو رواه عنه من رواه، وهذا أتى بأول الحديث وآخره، وبه أقول لأن الناس مسلطون على أموالهم، ليس لأحد أن يأخذها أو شيئاً منها بغير طيب أنفسهم إلا في المواضع التي تلزمهم، وهذا ليس منها، قلت وعلى قول مالك قال أبو الوليد الباجي 129: الذي يؤمر من حط عنه أن يلحق به هو السعر الذي عليه جمهور الناس، فإذا انفرد منهم الواحد والعدد اليسير بحط السعر أمروا باللحاق بسعر الجمهور، لن المراعي حال الجمهور،وبه تقوم المبيعات، وروى ابن القاسم 130 عن مالك، لا يقام الناس لخمسة، قال: وعندي أنه يجب أن ينظر في ذلك إلى قدر الأسواق، وهل يقام من زاد في السوق-أي في قدر

$$
121
$$

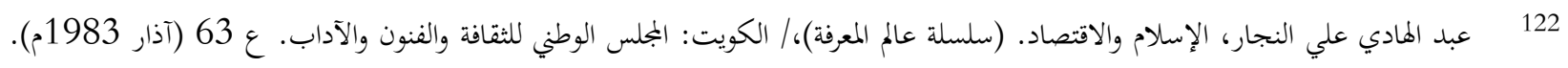

ابن جزي، قوانين الأحكام، مرجع سابق. ص 281 وشرح الزرقاني على موطأ مالك، مرجع سابق . ج 3 ص299.

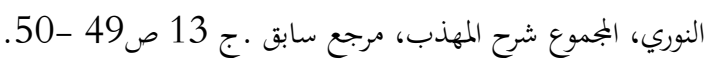

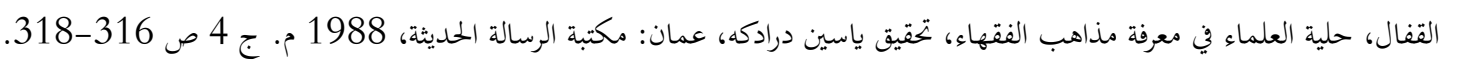

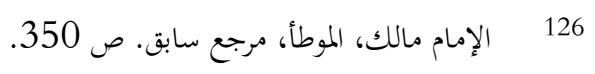

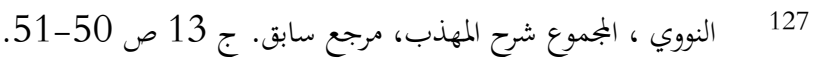

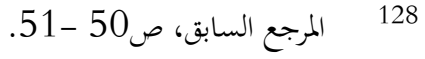

$$
\begin{aligned}
& 129 \text { أبو الوليد الباجي، المنتقى شرح صلموطأ، مرجع سابق. ج } 5 \text { ص } 17 \text { ص } 17 . \\
& 130
\end{aligned}
$$


المبيع بالدرهم مثلاًَ- كما يقام من نقص منه؟. قال أبو الحسن بن القصار المالكي: اختلف أصحابنا في قول مالك، ولكن من حط سعراً، فقال البغداديون: أراد من باع خمسة بدرهم والناس يبيعون ثمانية، وقال قوم من المصريين أراد من باع ثمانية والناس يبيعون خمسة، قال: وعندي أن الأمرين جميعاً منموعان، لأن من باع ثمانية والناس يبيعون خمسة

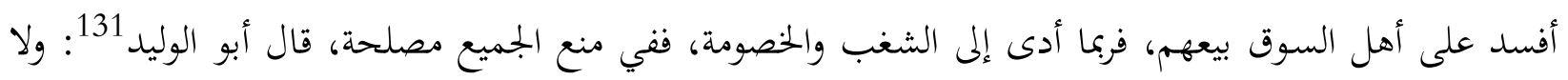
خلاف أن ذلك حكم أهل السوق، وأما الجالب ففي كتاب محمد لا يمنع الجالب أن يبيع في السوق دون الناس، وقال ابن حبيب ما عدا القمح الشعير إلا بسعر الناس وإلا رفعوا، قال: وأما جالب القمح والشعير فيبيع كيف شاء، إلا أن لهم في أنفسهم حكم أهل السوق، إن أرخص بعضهم تركوا، وإن كثر المرخص قيل لمن بقي إما أن تبيعوا

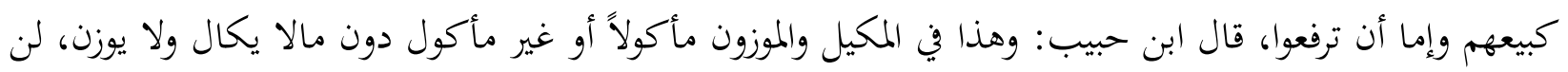
غيره لايمكن تسعيره لعدم التماثل فيه، قال أبو الوليد: يريد إذا كان المكيل والموزون متساوياً، فإذا اختلف لمس يؤمر بائع الجيد أن يبيعه بسعر الدون)

\section{وقد امتاز بحث ابن تيمية لمسألة التسعير بميزات منها:}

1-أنه ادخل في التسعير العادل أموراً كثيرة ولم يقصره على المواد التموينية والأقوات، فأدخل سلاح الجهاد والمابس وآلة الحج وماء الطهارة.

امتازت دراسة ابن تيمية للتسعير بأها دراسة نظرية لا دراسة تطبيقية، مما جعله يهتم بالمبادئ والكليات أكثر من اهتمامه بالتفصيلات.

3-اعتمد على رأيه مع أنه أورد الآراء الفقهية إلا أنه يبرز رأيه وتفكيره المستقل، ولم ينقل عن غيره إلا في مجال الإيضاح مع المحافظة على رأيه الشخصي. 4-اهتمامه بالعدالة عند التسعير وبما يهقق مصلحة الباعة والمشترين، فلا وكس ولا شطط133. وأشاد العديد من الكتّاب المعاصرين برأي شيخ الإسلام في التسعير، ومنهم، غازي عناية إذ يقول:

$$
\begin{aligned}
& 131
\end{aligned}
$$

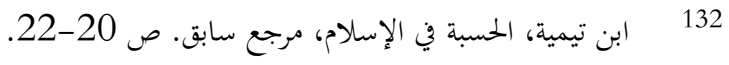

$$
\begin{aligned}
& \text { حمد بن عبد الرمن الجنيدل، مناه الباحثين في الاقتصاد الإسلامي، مرجع سابق. ج } 2 \text { ص ص 284-285. }
\end{aligned}
$$


"ولنا القول بالأخذ بما ذهب إليه شيخ الإسلام ابن تيمية، بأنه لايجوز التسعير إذا كانت الأسعار تتحدد وفق تفاعل عوامل العرض والطلب، ودون اتفاق من البائعين أو المشترين، وبان التسعير جائز إذا كان هنالك تواطؤ من

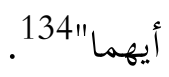

\section{ومنهم عبد الكريع زيدان، إذ يقول:}

"والراجح ما هذه إليه ابن تيمية رحمه الله، فلولي الأمر أن يسعّر السلع التي يجتاجها الناس بأن يضع لها سعراً عادلاً يلاحظ فيه مصلحة أرباب السلع، بأن يوفر لهم ربحاً معقولاً مناسباً ويلاحظ فيه مصلحة الناس المشترين، بأن يجعل السعر بقيمة المثل أو أزيد منه بقليل ولاشك في انم في التسعير تقييداً لحق المالك في التصرف في ملكه وكلنه تقييد للمصلحة العامة، والمصلحة العامة معتبرة في الشريعة، ومن ثم أجاز التسعير لأن الباعة لم يتصرفوا في ملكهم بمقتضى العدل الذي يلزمهم به الشرع، فكان لابد من قيام ولي المر بحملهم على ذلك عن طريق التسعير" 135.

\section{ومنه مصطفى حسين سلمان، إذ يقول:}

"وهذا الرأي الأخير - أعني رأي متأخري الحنابلة- هو الرأي الذي نميل إليه ونرجحه، لما فيه من إحقاق الحق ورفع الظلم عن فئة معين من المجتمع والمسألة في رأينا مبنية على التزام التجار بمنهج الله وتطبيق شريعته في الأرض، فإن تم ذلك فلا حاجة إلى إجبار الناس بالالتزام بالتسعير، أما إذا تعطلت أحكام الشرع وانحرفت الأمة عن منهاج الله فالتسعير يصبح واجباً، وبناء على ذلك نرى أن التسعير في أيامنا واجب شرعي، لبعد الأمة وانخرافها عن منهج الله

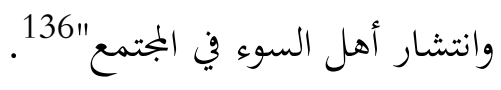

ومن المفكرين المعاصرين الذين جاء رأيهم في التسعير مطابقاً لرأي شيخ الإسلام ابن تيمية يوسف القرضاوي،حيث يقول،"إن الإسلام يعمل على إيجاد السعر التوازني العادل ن خلال إعمال آليات السوق، ومحاربة جميع الأوضاع الاحتكارية، كما ييجوز في الوقت نفسه لرئيس الدولة أن يتدخل في حالة الضرورة القصوى، ليحدد بعض أسعار السلع التي يتلاعب فيها التجار، بقصد تحقيق اربح الفاحش ضمن قواعد الإسلام الأساسية ومن أجل

$$
\begin{aligned}
& 134
\end{aligned}
$$

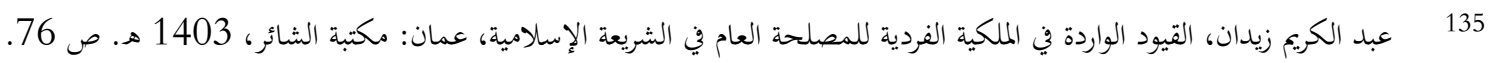

$$
\begin{aligned}
& 136
\end{aligned}
$$


ذلك نرى رسول الله صلى الله عليه وسلم حين غلا السعر في عهده والرسول يعلن من خلالها الحديث أن التدخل في حرية الأفراد بدون ضرورة مظلمة ولكن إذا تدخلت في السوق عوامل غير طبيعية كاحتكار بعض التجار وتلاعبهم بالأسعار، فمصلحة المجموع هنا مقدمة على حرية بعض الأفراد، فيباح التسعير الجبري استجابة لضرورة المجتمع أو حاجته وقاية له من المستغلين الجشعين وليس معنى الحديث السابق حظر كل تسعير، بل قرر المققون من العلماء وفي طليعتهم شيخ الإسلام ابن تيمية أن التسعير منه كما هو محرك ومنه ماهو عدل جائز "137. ثمن المثل: - n

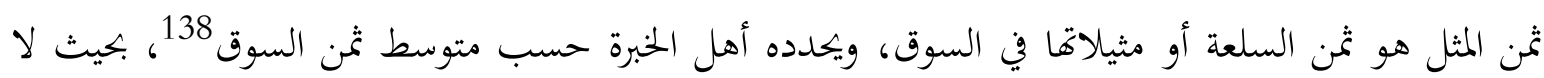
يلحق ضرراً أو ظلماً بأحد من أطراف السوق باعة ومشترين لذلك يجب أن يغطي هذا الثمن تكاليف الإنتاج أو الاستيراد مع هامش ربكي معقول 139، وبالمصلة فهو القيمة الحقيقية140 للسلعة وليس ثمن السوق أو الثمن الذي تراضى عليه المتبايعان في عقد البيع.

وقد عرّفه ابن تيمية بأنه سعر نفس السلعة في نفس المكان والزمان يقول: (ثمن المثل وهو السعر الذي يبيع به الناس، وهو ما ساغ به مثل تلك السلعة في ذلك المكان والزمان)141 ويربطه بما تعارف عليه الناس فيقول: (مثل المسمى في العرف)142، ويوضح ذلك قائلاً، (والعادة فإن المسمى في العقود نعان، نوع اعتاده الناس وعرفوه، فهو العوض المعروف المعتاد، ونوع نادر لفرط رغبة أو مضارة أو غيرها، ويقال فيه ثثن المثل، ويقال فيه المثل لنه بقدر مثل

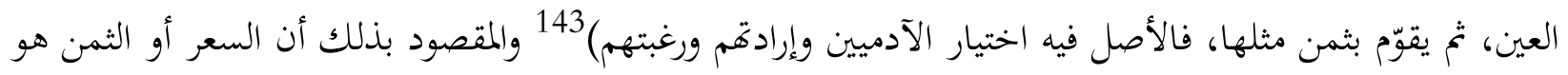
الذي يتحدد بين البائع والمشتري في الظروف غير العادية، كأن يقلّ عرض سلعة ويزداد الطلب عليها فيتحدد ثمن، أما

$$
\begin{aligned}
& 137 \text { التسعير الجبري للسلع من منظور إسلامي. تحقيق حمدي خلف، مجلة الاقتصاد الإسلامي ع } 197 \text { س } 17 \text { (ربيع الآخر } 1418 \text { هـ) ص } 66 . \\
& 138 \\
& 139 \\
& 140141
\end{aligned}
$$

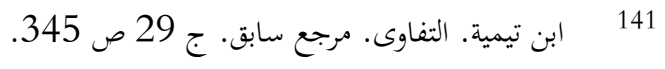

$$
\begin{aligned}
& 142 \\
& 143 \text { المرجع السابق. ص } 522 .
\end{aligned}
$$


السعر الذي يتحدد في الأوضاع والأحوال العادية نتيجة تلاقي الطلب الحقيقي المعبر عن رغبات الناس مع العرض الحقيقي للسع من قبل المنتجين، فهذا هو سعر المثل أو ثمن المثل.

ويتحدث انب تيمية عن السعر وقيمة المثل وثمن المثل بنفس الشيء، والسبب في ذلك حسب اعتقاد الباحث هو أن السوق الإسلامية يتولد فيها السعر الحقيقي الناتج عن رغبة حقيقية من المستهلكين، وعرض طبيعي من قبل الباعة دون شوائب، لذلك فالسعر المتولد هو السعر العادي أو الذي تعارف عليه الناس وهو قيمة السلعة الحقيقية، ويؤكد ذلك قول ابن تيمية، (ويف الجملة فقد فه النبي صلى الله عليه وسلم عن البيع والشراء الذي جنسه حلال حتى يعلم البائع بالسعر، وهو ثمن المثل)،144 وقوله: (والمسترسل الذي لا يماكس والجاهل بقيمة المبيع فإنه بمنزلة الجالبين الجاهلين بالسعر، فتبين انه يجب على الإنسان أن لايبيع مثل هؤلاء إلا بالسعر المعروف وهو ثمن المثل)، 145 ورغم ذلك فهو يتحدث أحياناً ميزاً بي ثثن المثل والسعر، فيقول: (والمقصود هنا انه إذا كانت السنة قد مضت في مواضع بأن على المالك أن يبيع ماله بثمن مقدر، إما بثمن المثل وإما بالثمن الذي اشتراه به). 146

ولا يغفل رحمه الله عن التأكيد على أن ثمن المثل يجب أن يكون متضمناً هامشاً ربحياً مقبولاً ومعقولاً لدى البائع، وإلا حدث خلل في السوق، يقول: (فلا يبيعون الحنطة والدقيق إلا بثمن المثل بحيث يربحون الربح بالمعروف من غير إضرار .كم ولا بالناس).

ويتحدث ابن تيمية عن مسوغات ثمن المثل، ويبين انه من باب اعتبار الشيء بمثله وتفعيل للعدالة والقسط والعرف، يقول: (ومداره على القياس والاعتبار للشيء بمثله، وهو نفس العدل ونفس العرف الداخل في قوله، ويأمرهم بالمعروف"148، "وأمر بالعرف"149، وهذا متفق عليه بين المسلمين، بل بين أهل الأرض، فإنه اعتبار في أعيان الأحكام لا في أنواعها، وهو من معنى القسط الذي أرس الله له الرسل وأنزل له الكتب، وهو مقابلة السنة بمثلها والسيئة بمثلها لكن مقابلة الحسنة بمثلها عدل واجب والزيادة إحسان مستحب والنقص ظلم محرم، ومقابلة السيئة

$$
\begin{aligned}
& 144 \text { ابن تيمية، الحسبة في الإسلام، مرجع سابق. ص } 27 . \\
& 145 \\
& 146 \text { ابن تيمية، الحسبة في الإسلام، مرجع سابق. ص } 26 . \\
& 147 \text { المربع السابق ص } 20 . \\
& 148 \\
& 149
\end{aligned}
$$


بمثلها عدل جائز والزيادة محرم والنقص إحسان مستحب، فالظلم للظالم والعدل للمقتصد والإحسان المستحب للسابق بالخيرات)

تم يتحدث عن مداره وكيفية تحديده مبيناً أنه يتحدد بناء على اطلب الحقيقي المضبوط بضوابط الحلال والحرام الشرعية، الناتج عن رغبة حقيقية في شراء تلك السلعة في الظروف العادية والطبعية، فيقول: (ولذا قال كثير من العلماء: قيمة المثل ما يساوي الشيء في نفوس ذوي الرغبات، ولابد أن يقال في الأمر المعتاد، فالأصل فيه إرادة الناس ورغبتهم، وقد علم بالعقول أن حكم الشيء حكم مثله، وهذا من العدل والقياس والاعتبار وضرب المثل الذي فطر الله عباده عليه، فإذا عرف أن إرادتم المعروفة للشيء بمقدار، علم أن ذلك ثمن مثله، وهو قيمته وقيمة مثله، لكن إن كانت تلك الرغبة والإرادة لغرض محرم كصنعة الأصنام والصلبان ونحو ذلك، كان ذلك العوض محرماً في الشرع، فعوض المثل في الشريعة يعتبر بالمسمى الشرع، وهو أن تكون التسمية شرعية وهي المباحة، فأما التسمية المخظورة،إما لجنسها كالخمر والخنزير، وإما لمنفعة محرمة في العين ونخو ذلك، فإن هذا ليس بتسمية شرعية فليسهو ميزاناً شرعياً يعتبر به المثل حيه لا مسمى)

ثم يذكر المؤثرات على الأسعار والتي يجب مراعاتا عند تحديد قيمة المثل 152 ويذكر منها:

1-زيادة عر السلعة وقلتا، يقول: (إذا عرف ذلك فرغبة الناس كثيرة الاختلاف والتنوع، فإها تختلف بكثرة

$$
\text { المطلوب وقلته فعند قلته يرغب فيه مالايرغب فيه عند الكثرة) }
$$

2-زيادة الطلب وقته على السلعة، يقول: (وبكثرة الطلاب وقلتهم فإن ما كثر طالبوه يرتفع ثمنه بخلاف ماقل

3-أهمية السلعة في حياة الناس، يقول: (وبحسب قلة الحاجة وكثرةا وقوتا وضعفها، فعند كثرة الحاجة وقوتا

$$
\begin{aligned}
& \text { ترتفع القيمة مالا ترتفع عند قلتها وضعها) } \\
& 150 \text { ابن تيمية. الثفاوى. مرجع سابق. ج } 29 \text { ص 521-522. }
\end{aligned}
$$

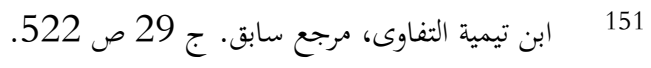

$$
\begin{aligned}
& 152
\end{aligned}
$$

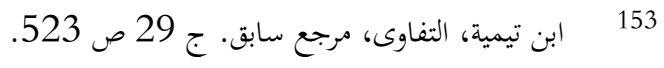

$$
\begin{aligned}
& 154
\end{aligned}
$$


4-الوضع المالي والاجتماعي للمشتري، يقول: (وبكسب المعاوض فإن كان مليّاً ديّناً يرغ في معاوضته بالثمن القليل، الذي لا يبذل بثله لمن يظن عجزه أو مطله أو حجده)

5-النقد وقوته، يقول: (ويحسب العوض نقد يرخص فيه إذا كان بنقد رائج مالايرخص فيه إذا كان بنقد آخر دونه في الرواج)

6- قدرة المشتري على الوفاء بالالتزامات، يقول: (وذلك أن المطلوب من العقود هو التقابض من الطرفين،

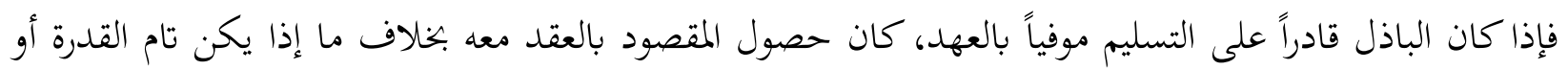

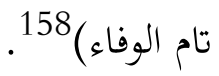

\section{وييين الحالات التي يلجأ فيها إلى تحديد ثمن المثل ويذكر منها:}

1-ضرورة الناس إلى السلعة، كمن عنده طعام زائد عن حاجته والناس في مجاعة، يقول: (ولهذا كان لولي الأمر

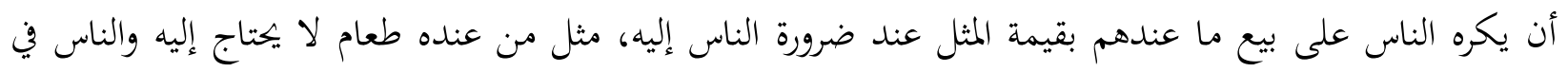
مخمصة فإنه يجبر على بيعه للناس بقيمة المثل) 159.

2-أن يمتنع الباعة من البيع مع حاجة الناس للسلعة، يقول: (وأما الثاني فمثل أن يكتنع أرباب السلع من بيعها

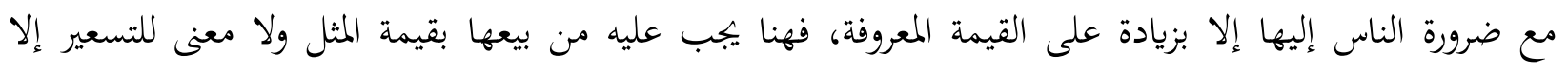
إلزامهم بقيمة المثل) 160.

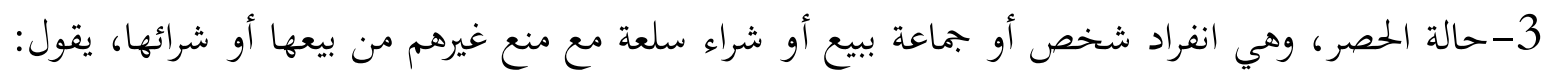

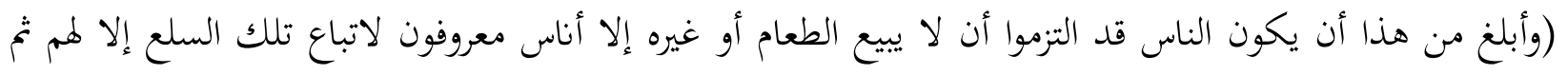

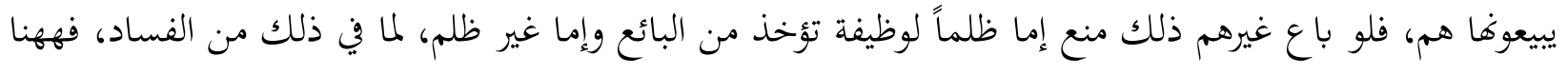

$$
\begin{aligned}
& 155 \\
& 156 \\
& 157 \\
& 158 \\
& 159 \text { ابن تيمية. الحسبة في الإسلام، مرجع سابق. ص } 124 \\
& 160
\end{aligned}
$$


يجب التسعير عليهم، بحيث لا يبيعون إلا بقيمة المثل ولا يشترون أموال النساء إلا بقيمة المثل بلا تردد في ذلك عند احد من العلماء)

4-الاضطرار إلى طعام الغير، يقول: (والإكراه على أن لايبيع إلا بثمن المثل لا يجوز إلا بحق، وييوز في مواضع مثل المضطر إلى طعام الغير) مُ

5-وجود بناء أو شجر في ملك الغير يتضرر صاحب الملك من دخول أو خروج الناس إليه، يقول: (ومثل الغراس والبناء الذي في ملك الغير فإن لرب الأرض أن يأخذه بقيمة المثل لا بأكثر) 163.

6-السراية في العتق، يقول: (وكذلك السراية في العتق، كما قالب النبي صلى الله عليه وسلم، "من أعتق شريكاً له في عبد، وكان له من المال ما يبلغ ثمن العبد، قوّم عليه قيمة عدل لا وكس ولاشطط، فأعطى شركاءه حصصهم،

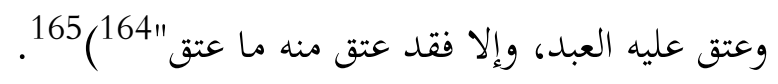

7-شراء مستلزمات العبادات، يقول: (وكذلك من وجب عليه شراء شيء للعبادات كآلة الحج ورقبة العتق وماء الطهارة فعليه أن يشتريه بقيمة المثل) 166.

8-النفقة الواجبة، يقول: (وكذلك فيما يجب عليه من طعام أو كسوة لمن عليه نفقته إذا وجد الطعام أو اللباس

$$
\text { الذي يصلح له في العرف بثمن المثل) } 167 .
$$

9-تواطؤ الباعة والمشترين، يقول: (فمنع البائعين الذي تواطؤا على أن لا يبيعوا إلا بثمن قدروه أولى، وكذلك منع المشترين إذا تواطؤا على أن يشتركوا ويكونون قد اتفقوا على ظلم الناس، حتى يضطر إلى بيع سلعهم وشرائها

$$
\begin{aligned}
& 161 \\
& 162 \\
& 163
\end{aligned}
$$

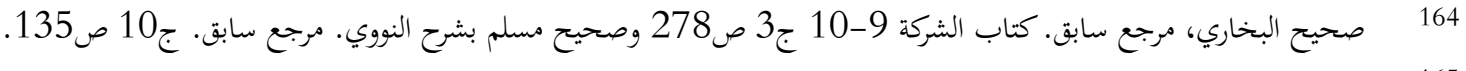

$$
\begin{aligned}
& 165 \\
& 166 \\
& 167
\end{aligned}
$$


بأكثر من ثثن المثل، والناس يمتاجون إلى ذلك وشرائه، وما احتاج إلى بيعه وشرائه عموم الناس فإنه يجب ألا يباع إلا بثمن المثل إذا كانت الحاجة إلى بيعه وشرائه عامة) 168.

10-الحاجة إلى سلاح ومستلزمات الجهاد، يقول: (وأما في الأموال فإذا احتاج الناس إلى سلاح للجهاد فعلى أهل السلاح أن يبيعوه بعوض المثل) 169.

11-الجمع بين شراء القمح وصناعة الخبز، يقول: (فلا يبيعوا الحنطة والدقيق إلا بثمن المثل، بحيث يربجون

$$
\text { الربح بالمعروف من غير إضرار بكم ولا بالناس) }
$$

ويرى الباحث أن ثن المثل هو الذي يمدده أصحاب الخبرة، اعتماداً على ثمن مثل السلعة في مثل السوق ومثل الظروف، وهو الثمن الحقيقي الذي يتولد من تقابل العرض السليم مع الطلب الحقيقي في الظروف العادية، ويستمر ويشتهر بين الناس حتى يتعارفوا عليه، وهو يختلف عن السعر الذي يتولد أحياناً في ظروف عدم توازن في العرض والطلب، وقد يكون أكثر أو أقل من سعر المثل. وسعر المثل يشم هامشاً من الربح ويحقق العدالة للبائعين والمشترين، ويلجأ إله عادة عندما لاتعمل قوى السوق ولا تعطي مؤشراً حقيقياً عن الأسعار، اعتماداً في تقديره على العرف والعادة ومشورة أصحاب الاختصاص، وفي حالات بّن بعضها شيخ الإسلام. والملاحظ انه في السوق الإسلامية المنضبطة بأخلاق وقيم تعاليم الإسلام، فإن السهر هو نفسه ثثن المثل في أغلب الأوقات، وإذا ما حدث خلل وأدى إلى فارق بينهما يتدخل ولي الأمر لإعادة الأمور إلى مسارها. 